\title{
Replication or Monopoly? The Economies of Invention and Discovery in Galileo's Observations of 1610
}

\section{The Argument}

I propose a revisionist account of the production and reception of Galileo's telescopic observations of 1609-10, an account that focuses on the relationship between credit and disclosure. Galileo, I argue, acted as though the corroboration of his observations were easy, not difficult. His primary worry was not that some people might reject his claims, but rather that those able to replicate them could too easily proceed to make further discoveries on their own and deprive him of credit. Consequently, he tried to slow down potential replicators to prevent them from becoming competitors. He did so by not providing other practitioners access to high-power telescopes and by withholding information about how to build them. This essay looks at the development of Galileo's monopoly on early telescopic astronomy to understand how the relationship between disclosure and credit changed as he moved from being an instrument-maker to becoming a discoverer and, eventually, a court philosopher.

The following revisionist account of the production and reception of Galileo's telescopic observations of $1609-10$ focuses on the relationship between credit and disclosure. Traditionally, the historiography on Galileo's discoveries has clustered around two very different views of evidence. Stillman Drake treated telescopic evidence as unproblematic, dismissing Galileo's critics as stubborn and obsurantist.' Others, instead, have argued that Galileo's discoveries were not self-evident

1 Stillman Drake contended that "the arguments that were brought forward against the new discoveries were so silly that it is hard for the modern mind to take them seriously" (Galilei 1957, 73). In his other publications on the subject, he focused on Galileo's process of discovery (especially in Drake 1976a, 153-168) but did not discuss the difficulties others may have faced in trying to replicate them. He only remarked that "good" astronomers had problems corroborating his claims because suitable telescopes were hard to come by in 1610 , and that "bad" philosophers were so committed to their bookish knowledge that they could not deal with Galileo's observations (Drake 1978, 159, 162, 165-6, 168). The telescope's epistemological status is treated as a non-problem, and perceptual issues are mentioned only in one case, to say that Galileo, because of an eye condition, had learned to peer 
and that their making and acceptance depended on specific perceptual dispositions (possibly connected to his training in the visual arts), commitments to heliocentrism, or unique (and perhaps tacit) skills at telescope-making. ${ }^{2}$

By questioning the transparency of the process of observation and discovery, the perceptual relativists have produced interpretations far more thoughtprovoking than Drake's. And yet they do not seem able to account for the fact that, despite all the perceptual and cosmological implications they find in Galileo's discoveries (and the ambiguous epistemological status of the instrument that produced them), his claims were commonly accepted within nine months from their publication in March $1610 .^{3}$ This is all the more remarkable considering that the satellites of Jupiter were not visible for about two months during that summer, contemporary networks of philosophical communication were neither broad nor fast, and the corroboration of Galileo's claims required learning how to construct and use a brand new kind of instrument. ${ }^{4}$

A different picture emerges when we shift our view to focus on Galileo's own observational protocols and how he did (or rather did not) heip others replicate his discoveries. Galileo, I argue, acted as though the corroboration of his observations

through his clenched fist or between his fingers to improve his sight and that this may have given him the idea to stop down the objective lens to improve its performance (ibid., 148).

2 Feyerabend looked at how Galileo's telescopic evidence (mostly about the moon) could convince other observers and readers (or rather how they could not convince them without additional ad hoc hypotheses and "propaganda" tactics). However, unlike Drake, he did not analyze Galileo's process of discovery or his own reasons to believe in what he saw. Feyerabend saw Galileo's telescopic evidence as simultaneously problematic and productive. In his view, Galileo's evidence was deeply problematic but it was only by being so that it triggered conceptual change. It could become unproblematic only later, once it was framed within a new set of "natural interpretations" (Feyerabend 1978,99-161). Like Feyerabend, Samuel Edgerton has studied Galileo's visual representations of the moon and has concluded that he was able to read the bright and dark patterns on its surface as pointing to physical irregularities (and to represent them in wash drawings that were then translated into engravings) because he had been trained in the artistic technique of chiaroscuro. Because of that training, Galileo saw the moon as a "landscape" and pictured it as such. Instead, astronomers like Harriot (who had observed the moon with a telescope a few months before Galileo) did not have the same artistic training, did not see what Galileo saw, and pictured the moon not as rugged but just as spotted (Edgerton 1984, 225-232). In part, Edgerton has relied on the work of Terrie Bloom who has argued that Harriot was able to "see" the spottedness of the moon as an index of its morphological irregularities only after he read Galileo's "Sidereus nuncius" and viewed its engravings. The Nuncius provided Harriot with the "theoretical framework" he needed to see what he couldn't see before (Bloom 1978, 117-22). Drawing a difference between encountering (or looking) and discovering, Bernard Cohen has argued that Galileo discovered what he did because of a theoretical mindset informed by a mix of anti-Aristoteleanism and incipient Copernicanism (Cohen 1993, 445-72). Van Helden, instead, has focused on the practical and perceptual challenges posed by early telescopes to argue that the making and replicating of Galileo's observations was a remarkable achievement, not a problem-free task. The conditions for such an achievement included suitable telescopes, considerable labor, appropriate observational setups, good eyesight, conceptual dispositions, and, ultimately, a tacit "gift" at observing.

3 I take the Roman Jesuits' confirmation of Galileo's claims on December 17, 1610, as a conservative date for the closure of the debate. For a summary of the controversial nature of Galileo's discoveries and instrument, see Galilei 1989, 88-90. In a different text, van Helden has remarked: "Now much has been made of the conservative opposition to these discoveries, but I should like to suggest that in view of the circumstances, the time it took Galileo to convince all reasonable men was astonishingly short" (Van Helden 1974, 51)

4 Galileo's manuscript log shows a gap in his observations of the satellites between May 21 and July 25 during Jupiter's conjunction with the Sun (Galilei 1890-1909, III:437-439). 
were easy, not difficult. His primary worry was not that some people might reject his claims, but rather that those able to replicate them could too easily proceed to make further discoveries on their own and deprive him of future credit (Galilei $1989,17)$. Consequently, he tried to slow down potential replicators to prevent them from becoming competitors. He did so by not providing other practitioners access to high-power telescopes and by withholding detailed information about how to build them. ${ }^{5}$

But as important as it was for Galileo to keep his fellow astronomers in the dark, such negative tactics alone would not have allowed him to gain credit from his discoveries and move from his post at the university of Padua to a position at the Medici court in Florence as mathematician and philosopher of the grand duke goals clearly on his mind in 1610 . He needed proactive tactics as well. First, he did his best to make sure the grand duke saw the satellites of Jupiter (which Galileo had named "Medicean Stars") by sending detailed instructions to Florence on how to conduct these observations, and then by going to court himself at Easter time (Galilei 1890-1909, X:281, 304). Second, through the prompt publication of the Sidereus nuncius in March of 1610 he tried to establish priority and international visibility - resources he needed to impress his prospective patron, not just the republic of letters.

The Nuncius was carefully crafted to maximize the credit Galileo could expect from readers while minimizing the information given out to potential competitors. Although it was researched, written, and printed in less than three months, it offered detailed, painstaking narratives of Galileo's observations and abundant pictorial evidence about his discoveries. It also said precious little about how to build a telescope suitable for replicating his claims.

Galileo gave a synthetic narrative (rich in dates and names but poor in technical details) of how he developed his instrument and remarked that one needed a telescope as good as his own to observe what he was describing in the book, but he did not tell his readers how he ground suitable lenses (which was the distinctive skill that gave him an edge over early telescope-makers), nor did he mention the dimension of his telescopes, the type of glass, the size and focal length of the lenses he used, and the diaphragm he had placed on the objective lens to improve its resolution (Galilei 1989,37$).{ }^{6}$ In the book, he provided only a bare diagram of the

5 Galileo's concerns with priority and monopoly have been noticed before. Drake has remarked on Galileo's reluctance to give out information about the telescope as an "unwillingness to give away advantages"(Drake 1970, 155). Albert van Helden and Mary Winkler have argued that "[Galileo] was able to monopolize telescopic astronomy for the first several years and make almost all the important discoveries" (Van Helden and Winkler 1992, 214-6). In a different text, van Helden remarked that "because he won the instrument race, Galileo was able to monopolize the celestial discoveries" (Van Helden 1984, 155). However, they have not seen these monopolistic tendencies as central to the story of the making and acceptance of Galileo's discoveries.

6 While other mathematicians besides Galileo were able to figure out the relationship between the focal length of the lenses and the enlarging power of the instrument, he was quickly able to develop remarkable skill at grinding lenses for telescopes. lenses that were outside of the standard repertoire of glass makers (van Helden 1984, 154-5). 
instrument and mentioned that his optical scheme involved a plano-convex objective and a plano-concave eyepiece (fig. 1). He also told his readers that unless one had at least a good 20-power telescope, "one will try in vain to see all the things observed by us in the heavens" (ibid., 38). He then proceeded to tell how to measure the enlarging power of telescopes, allegedly to prevent his readers from wasting their precious time trying to observe what they could not possibly see (ibid.). While he promised his readers a forthcoming book on the workings of the telescope, he never published it, nor do we have any manuscript evidence of such a project (ibid., 39). He presented his instrument as the standard of reference while

RECENS HABIT AE.
fpicillis ferantur fecundum lineas retractas E $Z_{H}$. E D 1. coardantur enim, \& qui prius liberi ad F G. Obiêtum dirigebantur, partem tantummodo HI. cō.

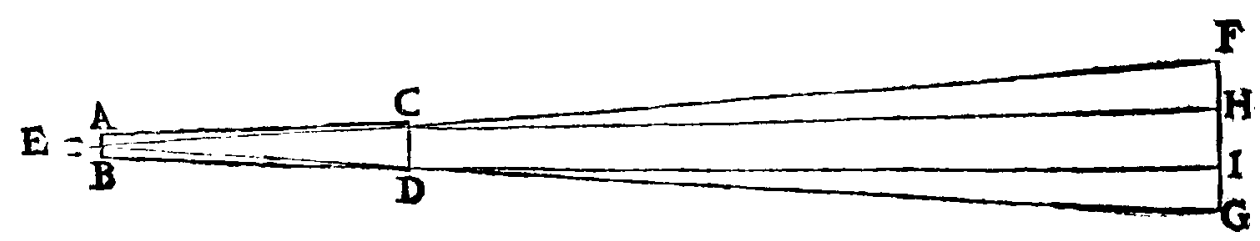

prahendent : accepta deinde ratione diftantix EH.ad lineam $H$ l. per tabulam finuum reperietur quantitas anguli in oculo ex obiecto $H$ I. conftituti, quem minuta quxdam tantum continere comperiem us. Quod fi Specilio $\mathrm{CD}$. bracteas, aliàs maioribus, aliàs verò $\mathrm{mi}$ noribus perforatas foraminibus aptauetimus, modo hanc modo illam prout opus fuerit fuperimponenres, angulos alios, atque alios pluribus, paucioribufquè minutis fubtendentes pro libito conf́tituemus, quorü ope Stellarum intercapedines per aliquot minuta ad. inuicem difftarum, fitra vnius, aut alterius minuti peccatum commodè dimetiri poterimus. Hæc tamen fic leuiter tetigiffe, \& quafi primoribus libafte labijs in profentiarum fic fatis, per aliam enim occafio nem abfolutam huius Organi theoriarn in medium pro. feremus. Nunc obfe iuationes àmobis duobus proximè elapfis menfibus habi cas recenfeamus, ad magnarú profectò contemplationum exordia omnes vera Philo. fophix cupidos conuocantes.
De facie aurem Lunx, quax ad alpectum noftrum vergis

Figure 1. Schematic diagram of the telescope in Galileo's Sidereus nuncius (Venice: Baglioni, 1610), p. 7 (reproduction courtesy of Owen Gingerich). 
withholding such a reference (but, as I will show in a moment, such a lack of disclosure did not necessarily destabilize his claims). ${ }^{?}$

This narrative seems to clash with the evidence that, shortly after the publication of the Nuncius, Galileo distributed several telescopes throughout Europe. The contradiction, however, is easily resolved. These instruments were sent to princes and cardinals, not to mathematicians. Princes and cardinals were not Galileo's peers but rather belonged to the social group of his prospective Medici patron. While their endorsements could strengthen Galileo's credibility with the grand duke, their social position prevented them from competing with him in the hunt for astronomical novelties. Furthermore, most princes and cardinals were already familiar with low-power telescopes because since 1609 glass-makers had been peddling these instruments to them, not to astronomers or philosophers. ${ }^{8}$ Galileo himself had heard of the telescope from people connected to diplomatic networks of correspondence. The first two instruments to come to Italy in 1609 were owned by Count de Fuentes in Milan and Cardinal Borghese in Rome. ${ }^{9}$ By the end of 1609 , low-power telescopes went from being wondrous devices to cheap gadgets (by nobles standards) produced in several Italian cities by traveling foreign artisans and local spectacle-makers (Galilei 1890-1909, X:248, 264, 252, 267, 282, 306). ${ }^{10}$ Princes sought and used telescopes on terrestrial and, more rarely, celestial objects well before rumors of Galileo's discoveries had began to circulate, and before most

7 At first, Galileo's tactics seem to resemble those of Newton during the debate on his theory of light and colors. Like Galileo, Newton withheld a great deal of information about the instruments he used in his early experiments (Schaffer 1989, 67-104). But if Newton's actions (while not motivated by priority concerns) clashed with the philosophical sociabilities of that time and put him at risk of being "given the lie," I hope to show that Galileo's tactics (whilst clearly driven by self-interest) were socially acceptable in the field in which he operated and were epistemologically justified by the specific observational practices within which he used the telescope.

8 Paolo Sarpi, the theological (and often technical) advisor to the Venetian Senate was Galileo's primary source of information about early telescopes, before one of them actually arrived in Venice in August 1609. Through his diplomatic connections, Sarpi had heard of the Dutch invention of the telescope in November 1608, and wrote about it to a number of correspondents in France. One of them, Jacques Badoer, wrote back from Paris in the Spring of 1609 with a more detailed description of the instrument which, by that time, was commonly sold by Parisian glass makers. Sarpi probably showed Galileo this letter in July 1609 (Galilei 1989, 37). On Sarpi's correspondence about early telescopes, see Drake 1970, 142-4.

9 On August 31, 1609 (a few days after Galileo presented his telescope to the Venetians), Lorenzo Pignoria wrote from Padua to Paolo Gualdo in Rome that Galileo's telescope was "similar to the one that was sent to Cardinal Borghese from the Fiandres" (Galilei 1890-1909, X:234, 255). It appears that Pignoria received news of the arrival in Rome of Cardinal Borghese's telescope in July (Galilei 1890-1909, X:226, 250). Girolamo Sirtori reported that an instrument was delivered to Count de Fuentes in Milan on May 1609 by a Frenchman (Sirtori 1618, 24-5). The presence of telescopes in Naples was already mentioned in an August 28, 1609, letter from Giovanni Battista della Porta to Federico Cesi (Galilei 1890-1909, X:230, 252). Porta did not say he owned a telescope, but that he had seen one, probably an instrument owned by a noble.

10 By March, telescopic observations of the moon were being conducted in Siena by Domenico Meschini, a gentleman who claimed to be in contact with other people in Rome who were also observing it with their own instruments. This is found in a postscript to a letter written to Galileo from Munich on April 14 paraphrasing a letter sent from Siena to Florence and then to Munich (Galilei 1890-1909, X:291, 341). In March 1610, Giovanni Battista Manso, a noble, wrote from Naples saying that, while the Nuncius had not yet arrived there, low power telescopes were available and were being used, with moderate success, to observe the irregularities of the moon (Galilei 1890-1909, X:274, 293). 
astronomers had developed any serious interest in telescopes. ${ }^{11}$ Emperor Rudolph II, for instance, observed the moon early in 1610 , before the Nuncius was published (Kepler 1965, 13). ${ }^{12}$ In Galileo's eyes, princes and cardinals constituted a low-risk, high-gain audience. Being more familiar with the telescope than Galileo's colleagues, they were likely to both appreciate the superior quality of his instruments and to corroborate his discoveries. At the same time, they were not going to compete with him and, having little professional and philosophical stake in his discoveries, they were less motivated to oppose them.

Galileo's differential treatment of his various audiences proved successful. He did take some short-term risk by relinquishing the credit he could have received from other mathematicians and astronomers through early widespread replications. But by the end of 1610 he had developed a monopoly on telescopic astronomy which he then maintained with the resources available to him as mathematician and philosopher of the grand duke of Tuscany. ${ }^{13}$

This essay looks at the development of Galileo's monopoly to understand how the relationship between disclosure and credit changed as he moved from being an instrument-maker to becoming a discoverer and, eventually, a court philosopher. My narrative does not follow a chronological order but is organized by a set of interrelated questions: How was Galileo enabled to make his observations? What kinds of textual information and skills were necessary to reproduce them? How could he justify his non-cooperative practices and yet have his findings accepted? What kinds of observational narratives could he develop to minimize disclosure and maximize credit? What was the relationship between the tactics of Galileo the inventor of the telescope and Galileo the author of the Nuncius? By following Galileo's trajectory from the development of the telescope in 1609 to the achievement of a Medici-based monopoly on telescopic astronomy in 1610, I show that he drew resources from various economies (of invention, of discovery, of artworks) without fitting completely into any one of them. ${ }^{14} \mathrm{I}$ argue that the categories "replication," "disclosure," and "evidence" need to be reframed within this hybrid economy - an economy that was different, in scale and structure, from that which emerged in late seventeenth century natural philosophy.

11 On April 1610, a diplomat from Modena wrote Count Ruggeri that Prince Paolo Giordano Orsini was back from the Netherlands where he had purchased a number of telescopes, probably to give them as gifts to other Italian princes who did not have them yet (Galilei 1890- 1909, X:304, 347).

12 Since September 1609, the Emperor had been purchasing telescopes from Venice (Galilei 1890-1909, X:241, 259) and perhaps others from northern Europe.

13 Van Helden has remarked on how quickly Galileo reacted to what he perceived as challenges to his status as the leading telescopic astronomer, and has explained that behavior as an expression of Galileo's concern with maintaining Medici patronage (van Helden 1984, 156-7). However, the relationship worked in the other direction as well, that is, Galileo's monopoly had been made possible by Medici patronage.

141 use the term "economy" to refer to systems of exchange, not just to monetary economies (capitalistic or otherwise). 


\section{Unaided Corroborations}

None of the astronomers or savants who reproduced Galileo's observations of the satellites of Jupiter by the end of 1610 did so with his direct help. The first independent confirmation came in May from Antonio Santini. A Venetian merchant with no particular background in astronomy, optics, or instrument-making, Santini was able to build a high-power telescope and observe the satellites of Jupiter within two months of the publication of the Nuncius. ${ }^{15}$ He conducted more successful observations in September, after the satellites had become visible again. ${ }^{16}$ Although he knew Galileo and was probably among those who performed observations with him at Padua or Venice, Santini received neither telescopes nor instructions as to how to grind lenses from Galileo. ${ }^{17}$ However, because he resided in a glass-making center and had probably seen the low-power telescopes that circulated in Venice since the summer of 1609 , Santini could have been in a position to replicate Galileo's skills by himself.

Kepler was the second to see the satellites in late August and early September 1610 with one of Galileo's instruments (Kepler 1611). However, that was not according to Galileo's plans because, as I discuss later, the telescope used by Kepler was not intended to go to him.

The third replication came on December 17 from the Jesuit mathematicians at

15 Santini was originally from I ucca. After his mercantile phase in Venice, he became a monk, and finally a mathematics professor in Rome (Galilei 1890-1909, XX:531-2). In a June 1610 letter to Galileo, Santini mentioned the observations of the satellites he had conducted some time before. The letter itself is a plea on behalf of Giovanni Magini to convince Galileo that Magini was not involved in Horky's printed attack on Galileo. The letter ends by saying that Magini had endorsed Santini's corroboration of Galileo's observations despite the fact that Magini, because of poor eyesight, had been unable to see them (Galilei 1890-1909, 10:337-378). By the end of May, Jupiter was too close to the Sun to be observed, which means that Santini's observations must have been carried out in the second half of May at the latest. On September 25, Santini confirmed to have clearly seen the satellites of Jupiter before conjunction Giove vespertino (Galilei 1890-1909, X:397, 435). That Santini's observations were not made through Galileo's telescope but through an instrument of his own production is supported by the fact that by June Santini was already a supplier of good lenses and telescopes to Magini (Galilei 1890-1909, X:338, 378-9) and that, in the several letters exchanged with Galileo during 1610 he never mentioned having observed with him. Santini's corroboration was made public in Roffeni's Epistola apologetica contra caecam peregrinationem cuiusdam furiosi Martini (Bologna: Rossi 1611, reproduced in Galilei 1890-1909, I1I, Part I: 198).

16 Santini's observations are reported several months after they took place (or perhaps earlier letters mentioning them are lost). In a September 25 letter to Galileo, Santini wrote: "Finalmente mi risolsi di rivedere Giove mattutin, se bene, per quello aspetta a me, haveo tanta confermassione dall'averlo visto vespertino, che non dubitavo se li pianeti intorno a esso da lei scoperti vi fossero o no (se però non si desse là sopra qualche alterassione). Lo rivedetti lunedimattina, alle ore 10 , giorno che fu de' 20 stante, e trovai li 4 pianeti tutti orientali. Alli 23 poi li riveddi del modo che notiro' da basso [one to the left and three to the right of Jupiter]" (Galilei 1890-1909, X:397, 435). That Santini's September observations were cast as a belated re-checking "I finally decided to see Jupiter again," not as an urgent matter, confirms Santini's confidence in his earlier corroborations.

17 It is possible Santini inspected one of the many low-power telescopes available in Venice since the autumn of 1609 . However, he didn't necessarily need to have access to that information. It appears that several of the mathematicians and glass makers who produced early low-power telescopes (Harriot, Marius, Galileo, Lipperhey, Janssen, and Metius) did so after receiving only a verbal description of them (van Helden 1974, 39 n. 3). 
the Collegio Romano. ${ }^{18}$ They too had not received telescopes or instructions from Galileo, but used instruments sent them by Santini or produced locally by one of Clavius' students, Paolo Lembo, and perfected by Grienberger, a fellow-Jesuit (Galilei 1890-1909, XI:466, 33-4). Neither Lembo nor Grienberger had previous experience making optical instruments. Two other successful observations of the satellites were achieved in 1610 in France (Peiresc and Gaultier, November 1610) and England (Harriot, October 1610) - both of them without any direct help from Galileo or his telescopes. ${ }^{19}$

Galileo's tendency not to share telescopes or information about their construction was most striking in Kepler's case. Just a month after the publication of the Nuncius, Kepler had endorsed Galileo's discovery of the satellites of Jupiter in a long letter which was immediately published as the Dissertatio cum nuncio sidereo. ${ }^{20} \mathrm{Kepler}$ publicly endorsed Galileo's discoveries despite the fact that he was not able to replicate them because, at that time, he had access only to low-power instruments owned by his patron, Rudolph II (Kepler 1965, 13).21 These instruments were powerful enough to observe the irregularities of the lunar surface, but their magnification and clarity was not sufficient to detect the satellites of Jupiter. In August, Kepler pleaded with Galileo to send him a telescope saying "You have aroused in me a passionate desire to see your instruments, so that $I$ at last, like you, might enjoy the great spectacle in the sky" (Galilei 1890-1909, X:374, 413-4). ${ }^{22}$

Although by this time Galileo had already sent instruments to princes and cardinals (and was in the process of sending more), he did not oblige Kepler. He excused himself by suggesting that Kepler deserved only the best of telescopes, which unfortunately Galileo no longer owned because it had been placed "among

18 Clavius confirmed the existence of the satellites in a December 17 letter to Galileo (Galilei $1890-1909, X: 484-5)$. The Jesuits had been recording their sightings of the satellites since November 28 (Galilei 1890-1909, 3, Part 2:863), but had observed them also on November 22, 23, 26, and 27 - as reported by Santini to Galileo in a December 4 letter in which he also included diagrams of the Jesuits' observations (Galilei 1890-1909, X:479-80). The Jesuits seemed particularly cautious. Clavius had written Santini that, even after the November 22-27 observations, "we are not sure whether they are planets or not" (ibid., X:480). Others seem to have observed the satellites in Rome before the Jesuits. In a November 13 letter to Galileo, Ludovico Cigoli stated that Michelangelo Buonarroti, a friend of Galileo and Cigoli's, had been an eyewitness testimonio oculato of the satellites on several occasions, and that his testimonials had been able to convince a few skeptics (ibid., $\mathrm{X}: 428,475$ ). Moreover, in a June 7 letter to Galileo, Martin Hasdale wrote from Prague that he had received a letter from Cardinal Capponi in Rome saying that Roman mathematicians approved of Galileo's discoveries, though he did not mention names (ibid., X:328, 370).

19 These replications had no historical role in the story I am telling here. On these observations, see Roche 1982, 9-51; Humbert 1948, 316. In 1614, Simon Marius, a German mathematician claimed to have discovered Jupiter's satellites earlier than Galileo, but his claims have been disputed since (Galilei 1989, 105 n. 6I). Marius' priority claims are in his Mundus Jovialis, translated in Prickard 1916, 367-503.

20 Kepler's letter to Galileo was dated April 19, 1610 (Galilei 1890-1909, X:297, 319-40). The dedication of the printed version is dated May 3, 1610.

21 For a discussion of some of Kepler's reasons for endorsing Galileo's claims without being able to replicate them, see Biagioli forthcoming.

22 Kepler continued: "Of the spyglasses we have here, the best ones are ten-power, others threepower. The only twenty-power one $I$ have has poor resolution and luminosity. The reason for this does not escape me and I see how I could make it clearer, but we don't want to pay the high cost." 
more precious things" in the grand duke's gallery to memorialize the discovery of the Medicean Stars (Galilei 1890-1909, X:379,421). Galileo also intimated that, at the moment, he was temporarily unable to produce more instruments because, being in the process of moving from Padua to Florence, he had disassembled the machine he had constructed to grind and polish lenses (Galilei 1890-1909, X:379, 421). ${ }^{23}$ The Emperor too had requested (with some insistence) an instrument through the Medici ambassador in Prague, and had vented his frustration at not being given priority over cardinals whom he knew Galileo had provided with telescopes. ${ }^{24}$ However, the imperial pleas, like Kepler's, went unanswered. When Kepler finally observed the satellites of Jupiter in August and September and published his findings in another short text, the Narratio de observatis a se Quattuor Iovis satellitibus erronibus, he did so with a telescope Galileo had sent to the Elector of Cologne - not to him or to the Emperor. ${ }^{25}$

Galileo's behavior may seem particularly ungrateful as Kepler's Dissertatio was the first and only strong endorsement he had received from a well-known astronomer before he obtained his position at the Medici court in the summer of 1610 . Thanks to Kepler, Galileo was able to confront his critics with a powerful testimonial and to quench some of the Grand Duke's anxieties about having his family name attached to artifacts. Perhaps Galileo thought that, given Kepler's commitment to the Copernican cause, he would have supported his discoveries anyway (which he did) and that, therefore, he did not need any further help or sign of gratitude. Moreover, in the Dissertatio, an enthusiastic Kepler exclaimed: "I should rather wish that I now had a telescope at hand, with which I might anticipate you in discovering two satellites of Saturn"(Kepler 1964, 14). The use of

23 On October I, Galileo's lens-grinding machines (which he said had to be set in place with mortar) were still inoperative (ibid., $\mathrm{X}: 402,440$ ).

24 Giuliano de' Medici to Galileo, April 19, 1610 (Galilei 1890-1909, X:.296, 319). In July, better telescopes reached Prague from Venice, but none of them were made by Galileo (ibid., X: 360,401-2). On July 19, Giuliano de' Medici acknowledges the arrival of additional ephemerides of the satellites (not telescopes) Galileo had sent to Kepler (ibid., X: 362, 403). In the same letter, he urges Galileo to send an instrument to the Emperor (ibid., X:404). On August 9, Galileo is told that the Emperor has received a better telescope from Venice, but that Galileo's instrument (that some thought had been received by the Medici ambassador) had not yet been seen (ibid., X:375, 418). It does not appear it was ever there, as on August 17 Galileo is told of the Emperor's aggravation (ibid., X:378, 420). Interestingly, the imperial court at Prague was not on the first list of potential recipients of telescopes Galileo submitted to the Medici on March 19 (ibid., X:277, 298, 301), but was added only in May (ibid., X:311,356). While much of the evidence points to the fact that Galileo did not wish Kepler to have a telescope, on May 7 he asked the Medici for permission to send one in the diplomatic pouch from Venice to Prague. He also remarked that he did not have any good telescopes ready (ibid., X:307, 349-50). The Medici authorized the shipment on May 22 (ibid., X:311, 356), but on May 29, the Medici resident in Venice expresses worries that the telescope could get damaged during shipping (ibid., $X: 323,364)$. That does not seem to have been a problem as often telescopes were shipped disassembled. It could be that Galileo thought it would be useless to send a telescope to Prague at the end of May as Jupiter was no longer observable, and that he could have taken the two months before it became visible again to produce a better instrument. However, he never sent such an instrument, probably because, by the time Jupiter was visible again, he had already received a contract from the Medici.

25 In September 1610, Giuliano de' Medici informed Galileo of Kepler's observations and of his decision to publish the Narratio (Galilei 1890-1909, X:329). 
the verb "to anticipate" may have drastically decreased Kepler's chances of receiving the instrument he sought.

Galileo displayed a similarly uncooperative attitude toward other potential allies. ${ }^{26}$ On April 17, Ilario Altobelli asked him for lenses or a telescope so that, he claimed, he could help Galileo with testimonials against his critics. But he seemed a bit too eager to determine the periods of the Stars and received nothing in the end. ${ }^{27}$ Magini, who had been one of Galileo's early detractors but had slowly changed his mind, asked him for a eyepiece on October 15, but was not gratified. ${ }^{28}$

Galileo did not help the Jesuit mathematicians of the Collegio Romano either. Right after moving back to Florence from Padua in September 1610, he wrote Clavius that he had heard the Jesuits were having problems seeing the satellites of Jupiter. That did not surprise him, Galileo continued, as he knew all too well that one needed an "exquisite instrument" to replicate his observations (Galilei 1890-1909, X:391, 431). However, he did not volunteer to send Clavius such an exquisite telescope but simply advised him to build a sturdy mount for whatever instrument he had because even the small shaking caused by the observer's pulse and breathing was enough to disrupt the observations (ibid., 431). He concluded that, in any case, he would show Clavius the "truth of the facts" during his forthcoming visit to Rome (ibid., 432). On October 9, Santini wrote Galileo that the Jesuits had not yet seen the satellites and added that "I think that these big shots, I mean in term of reputation, are playing hard to get so that Your Lordship may feel obliged to send them an instrument."29 Even then, however, Galileo did not send the Jesuits a telescope.

He was much more forthcoming with patrons and courtiers. In a January 7 letter written from Padua (either to Antonio de' Medici or Enea Piccolomini) Galileo gave more useful tips about the telescope than in the Nuncius or in anything else he wrote that year. In it, he told the Florentine courtier (whom he was probably instructing how to show the satellites to the grand duke) how to minimize the shaking of the telescope caused by the observer's heartbeat and breathing, how to maintain the lenses, and how much excursion one should allow the tubes carrying the two lenses so as to achieve proper focusing (as he probably had sent or was planning to send him two lenses but no casing) (Galilei 1890-1909, $\mathrm{X}: 259,277-8) .{ }^{30}$ More importantly, he stressed that the objective lens needed to be

26 Raffaello Gualterotti requested lenses on March 6, 1610, (Galilei 1890-1909, X:268, 287) and Alessandro Sertini on March 27, 1610 (ibid., X:282, 306).

27 "et $m$ 'ingegnero" d'adattare il tubo in forma della fiducia nel dorso dell'astrolabio per osservare anco $i$ periodi; e scrivero' a V.S. il tutto in lingua latina, accio' lo possi poi annettere nelle sue osservationi" (Altobelli to Galileo, April 17, 1610 [Galilei 1890-1909, X:294, 317]).

28 Magini said to have received three large lenses from Santini, and that he thought to have a very good one among them. But he lacked good eyepieces, and asked Galileo to send some (Galilei $1890-1909, \mathrm{X}: 408,446)$.

29 "Io dubito che alcuni di questi pezzi più grossi, voglio dire di più riputassione, non stiano duri, accio' V.S. si metta di necessità di mandargli lei uno instrumento" (Galilei 1890-1909, X:407, 445).

30 However, we do not have any evidence that Galileo actually sent the lenses or a telescope to Florence before his visit during the Easter vacation. The only mention of a telescope in Florence is from April 20,1610 (Galilei 1890-1909, X:299, 341). The letter mentions a telescope kept in the 
stopped down with a diaphragm. As the lenses' shape was particularly irregular toward the edges, covering that part would significantly reduce aberrations. Clavius was told by Galileo of this significant tip almost a year later (after he confirmed the satellites' observation in December 1610) and only because the Jesuit had asked Galileo why the telescopes he had sent to Rome (to cardinals) had stopped-down objectives. ${ }^{31}$

Predictably, Galileo did not loan his own instrument. He organized or participated in public observational seances in Venice, Padua, Bologna, Pisa, Florence, and later in Rome, but it appears that he never left the telescope in alien hands, not even for a few hours. ${ }^{32}$ These meetings were meant to provide demonstrations rather than to foster independent replications. Galileo would arrive, demonstrate, and depart. While people could look through the telescope, it appears that they did not have much of a chance to look at or into it. During his visit to Bologna in April 1610, Martinus Horky had to sneak around Galileo's guard (probably while he was asleep) to make a cast of the telescope's objective lens (Galilei 1890-1909, $\mathrm{X}: 301,343)$.

Galileo's fears about the consequences of giving good telescopes to mathematicians or helping them construct their own were not unjustified. He knew from personal experience that, after receiving an approximate verbal description of a telescope, one could build a prototype in a single day, move from 3-power instruments to 9-power telescopes in a few weeks, and that it was possible to develop a 20-power instrument in about four months and a 30-power one in less than seven months. ${ }^{33}$ Soon after, he witnessed a merchant like Santini build telescopes good enough to observe the satellites of Jupiter within two months from the publication of the Nuncius in March, and then supply lenses and entire telescopes to both Magini and the Roman Jesuits. ${ }^{34} \mathrm{He}$ also knew that increasingly powerful instruments were being constructed in Venice and elsewhere. ${ }^{35}$ For

Medici storage rooms, but does not say it is by Galileo. Also, because Galileo was in town at that time (and is actually mentioned in the letter), this could be an instrument he had brought with him from Padua.

31 Clavius's query is in (Galilei 1890-1909, X:437,485). Galileo's response is in (Galilei 1890- 1909, $\mathrm{X}: 446,501$ ): "Hora, per rispondere interamente alla sua lettera, restami di dirgli come ho fatto alcuni vetri assai grandi, benchè poi ne ricuopra gran parte, et questo per 2 ragioni: l'una, per potergli lavorare più giusti, essendo che una superficie spaziosa si mantiene meglio nella debita figura che una piccola; l'altra è che volendo veder più grande spazio in un'occhiata, si può scoprire il vetro: ma bisogna presso l'occhio mettere un vetro meno acuto et scorciare il cannone, altramente si vedrebbero gli oggetti assai annebbiati. Che poi tale strumento sia incomodo da usarsi, un poco di pratica leva ogni incomodità; et io gli mostrerò come lo uso facilissimamente."

32 Galileo to Kepler, August 19, 1610 (Galileil890, X:379,422). On meetings in Venice and Padua see Galileo to Vinta, March 19, 1610 (Galilei 1890-1909, X:277, 301).

33 On Galileo's quick progress, see van Helden 1984, 150-5. On the earlier developments of the telescope, see van Helden 1977, Part 4:1-67.

34 Santini's lenses and telescopes to Magini are mentioned in Galilei $1890-1909$, X:338, 378; 356 , $398 ; 408,446 ; 400,437 ; 414,451$. On Santini's gifts of telescopes to the Jesuits, see ibid., XI:466, 33-4.

35 Galileo's correspondence indicates that by mid-1610, low-power telescopes were common, their price had dropped, and the market was so saturated that some telescope-makers were moving on to other (probably more provincial) cities. Then, Magini wrote him in October that Cardinal Giustiniani had managed to attract to Bologna a skilled glassmaker from Venice ("Bortolo," the son of the 
instance, his friend Castelli reported that at the beginning of February a friar, Don Serafino da Quinzano, had shown him the moon through a 9-power telescope that he had built on his own (Galilei 1890-1909, X:287, 310-1).

His worries would have only been increased had he known of the Jesuits' quick progress. ${ }^{36}$ By the end of 1610 Grienberger had successfully modified the eyepiece of a second good telescope Clavius had received from Santini thereby turning it into a 34-power instrument (ibid., XI:466, 34) ${ }^{37}$ According to Grienberger, this telescope was better than those produced by Galileo which the Jesuits had been able to test in Rome (telescopes Galileo had sent to cardinals, not to astronomers). According to information provided by Grienberger, the power of this instrument was somewhat superior to anything Galileo had produced at that time. The fact that making telescopes was a quickly-spreading skill was evident not only to Galileo. At the end of September 1610, Santini wrote him: "I do not understand, now that the telescope has become so common and easy, how come the practitioners of the speculative sciences have not managed to clarify this matter [the existence of the satellites] and express their consensus." ${ }^{38}$ The issue, then, was not whether people could develop powerful telescopes, but only how many weeks or months it would take them to move from 3-power to 20 -power instruments. ${ }^{39}$

That Galileo worried about priority disputes rather than about the difficulties others might face in replicating his discoveries is confirmed by his statement that the Nuncius had been "written for the most part as the earlier sections were being printed" for fear that by delaying publication he would have "run the risk that someone else might make the same discovery and preceded me [to print]" (Galilei $1890-1909, \mathrm{X}: 277,300)$. The way Galileo behaved in 1610 suggests he thought he had only a limited amount of time to discover whatever there was to be discovered with telescopes of that power range. ${ }^{40}$ As he put it in the Nuncius, "Perhaps more

Emperor's glassmaker) who was quite good at grinding lenses for long (that is, high-power) telescopes and that Magini planned to use his services (Galilei 1890-1909, X:408, 446). On October 15, 1609 , Lorenzo Pignoria wrote from Padua that there were "most excellent telescopes," adding that they were produced by a few artisans, that is, not just by Galileo (ibid., 243, 260). Hasdale wrote to Galileo from Prague that the Emperor was getting increasingly better telescopes from Venice, one of which, apparently, had been produced by an artisan who worked for Galileo (ibid., 360, 401-2). On April 24, Gualterotti mentions a good telescope made by "Messer Giovambattista da Milano" whose quality Galileo appears to have praised (ibid., 300, 341). Santini sent a new telescope to Florence (to the Venetian ambassador) on November 6, 1610, and asked Galileo to take a look at it (ibid., 423, 464-5). Galileo liked it (ibid., 433, 479).

36 Since the summer of 1610 , the Roman Jesuit Paolo Lembo had been producing increasingly good telescopes with which the mathematicians of the Collegio Romano were eventually able to see the satellites - though only when the sky was very clear. According to Grienberger, Lembo had developed his tirst telescopes on his own, without information or examples from the outside (Galilei I890-1909, XI:466, 33-4).

37 I wish to thank Albert van Helden for decoding this figure from Grienberger's letter.

38 "Io non so come, essendosi fatto tanto comune e facile questo uso del cannone, non sia da quelli che attendono alle specolative chiarito questa partita e dato l'assento" (Galilei 1890-1909, X:397, 435).

${ }^{39}$ Harriot, for instance, had a 10 power telescope by July 1610 , a 20-power by August, and a 32-power by April 1611 (Roche 1982,17).

${ }_{40}$ The first phase of the race for telescopic discoveries was effectively over by 1612 with the 
excellent things will be discovered in time, either by me or by others, with the help of a similar instrument"(Galilei 1989, 36). Even the first available report about the use of the telescope indicates that those who managed to construct or have access to an instrument quickly pointed it to whatever celestial body they could spot. ${ }^{41}$ How close the race must have been can be gathered from a January 1611 letter from Grienberger to Galileo in which he mentioned that even before the Jesuits had heard about his discovery of the phases of Venus at the end of December, they had independently observed them (Galilei 1890-1909, XI:466, 34).

While cosmological commitments may have played a role in setting the direction of further observations (as in the case of the discovery of the phases of Venus), this astronomical hunt seemed primarily propelled either by plain curiosity or by the desire to discover more novelties and get credit for them. Considerations of the possible pro-Copernican or anti-Ptolemaic significance of these discoveries were not a common concern in the first half of 1610 , but emerged after Galileo's claims had been accepted (Biagioli 1993, 94-6).

Because of the speed with which others were learning how to build telescopes suitable for astronomical use, Galileo's uncooperative stance may have been the determining factor in achieving a monopoly over that first astronomical crop. He was first to discover the unusual appearance of Saturn (in the summer of 1610) and the phases of Venus (in the fall), and to determine the periods of the satellites - a result that both reinforced the epistemic status of the Medicean Stars and brought him more visibility. ${ }^{42} \mathrm{H}$ is monopoly became almost self-sustaining. He managed to reclaim credit for the discovery of the sunspots from the Jesuits (although they had been first to publish that discovery late in 1611) and, years later, he succeeded in defending the referential status of his telescopes when other instrument-makers, like Fontana in Naples, had produced more powerful ones. ${ }^{43}$

discovery of sunspots. The second wave of discoveries started only in 1655 with Huygens (Van Helden $1984,155)$.

\1 Ambassades du Roy de Siam envoyé à l'Excellence du Prince Maurice, arrivé à la Haye le 10. Septemb. 1608 reports that one of the very early telescopes had been aimed at the stars in the Netherlands as early as fall 1608 (The Hague 1608,11 ).

42 In the Nuncius, he exhorted other astronomers to find the satellites'periods (Galilei 1989, 64). By this time he had only a figure for the outer satellite, which he put at about fifteen days (Galilei $1890-1909, X: 271,289)$. That figure was corrected to more than sixteen days in the spring 1611 (ibid., XI:532, 114). There he also gave estimates for the period of the innermost at less than two days. He published his first full description of the satellites periods in 1612 in his Discourse on Bodies in Water. Those values were very close to modern ones. On Galileo's investigation of these periods, see Stillman Drake 1979, 75-95.

43 "From an early point, then, the authority of instruments was intertwined with personal authority. A strong argument can be made that after about 1612, Galileo's lead in telescope making had disappeared and that others had instruments of comparable quality. Yet Galileo ruled until his death as the undisputed master of telescopic astronomy (van Helden 1994, 19). On related issues, see also van Helden and Winkler 1992, 214-6. 


\section{A Field, not a Community}

Galileo's non-cooperative attitude and his focus on developing a Medici-based monopoly of telescopic astronomy reflected more than just his fears about being deprived of credit for future discoveries. Galileo and his readers did not belong to a professional community that could provide the kind of credit and rewards he sought. Furthermore, the lack of consensus about style of argumentation and standards of evidence as well as the scant interdependence among the members of this field hindered closure of the debate. ${ }^{44}$

Galileo's correspondence shows that his discoveries were discussed in a field geographically dispersed over several courts and universities or punctuated by isolated individuals linked only through selective correspondence networks. It included few professional astronomers but many physicians, men of letters, diplomats, students, polymaths, and variously educated gentlemen. Political and religious boundaries mattered. A French or German mathematician did not have much incentive to engage, or even less to agree with the claims put forward by someone who operated on the other side of the Alps - unless, as in Kepler's case, the legitimation of those claims could provide him with further resources for his own Copernican program.

Of the several critiques of Galileo's findings that circulated in 1610 , only one made it to print (Horky 1610, 129-145). ${ }^{45}$ Critiques were more commonly presented first in private conversational settings and then communicated, often anonymously, through networks of scholarly and courtly correspondence and gossip. The remarkable metamorphoses that affected what went in and out of these channels did little to stabilize the debate. The proliferation of opinions was also fostered by the courtly format in which many of these views were presented and developed (Biagioli 1993, 72-83). Upon receiving a copy of Galileo's Nuncius, a prince or his courtiers could ask court mathematicians and physicians for an opinion about the book. Critical responses were almost de riguer in these contexts as they could generate lively and entertaining debates, but, by the same token, they did not tend to facilitate closure. ${ }^{46}$

\footnotetext{
44 My analysis is broadly informed by Pierre Bourdieu's notion of "field," and especially by his discussion of how fields are established (Bourdieu 1985, 723-44; idem 1999, 31-50).

45 A second critique (Sizi 1611, 203-250) was written in 1610, but was published only in 1611 , after Galileo's claims had been widely accepted. It had little or no impact on the debate.

46 These people were given little time to formulate their views and often were expected to respond on the spot, sometimes without having seen the book or tried a telescope. Because of this conversational format, commentators were only moderately accountable for their views and could modify or even reverse them at a moment's notice without much embarrassment or professional liability. For instance, a major astronomer like Magini could support (and largely share) Martinus Horky's vehement critique of Galileo (Galilei 1890-1909, X:303, 345;324, 365), but then turn around and write (or have others write) that he was a Bohemian madman as soon as Horky's attack on Galileo seemed to backfire (ibid., $X: 334,376 ; 335,377 ; 337,378 ; 338,379 ; 344,384-5$ ). In a differently structured republic of letters, the remarkable contradiction between Magini's public and private stances may have not been without liabilities. Moreover, some of these critiques seemed to be aimed not so much at
} 
To modern ears, the tone of several of these early critiques may appear harsh, even libelous. However, it would be wrong to take this simply as a sign of strong emotions stirred by cosmological and philosophical incommensurabilities. More mundanely, such a tone reflected the kind of discourse generated by controversial novelties (and by the sudden stardom of their producer) in a dispersed and marginally interdependent field. ${ }^{47}$ The same field that allowed Galileo to adopt an uncooperative stance toward other astronomers did not compel his critics to treat him respectfully either (Biagioli 1993, 60-73). Although the Nuncius triggered many conversations, their end point was conversation, not closure. The Nuncius was like a message in a bottle, a carefully packaged message let to drift, hoping for the best.

\section{Periodic Evidence vs. Instantaneous Perception}

At first glance, the Nuncius appears to present a straightforward account of sequential observations. But the narrative structure that wove these observations into physical claims displayed a kind of demonstrative logic - a logic that well matched Galileo's epistemological and social predicament at the beginning of 1610.

Galileo's first goal was to gain assent for his claims, minimize the risk of losing priority over future discoveries, and cast his reluctance to provide information about the telescope as inconsequential to the acceptance of his discoveries. Second, he could not present himself as someone whose claims could be accepted on the grounds of his personal credibility. By the time the Nuncius was published, few readers knew of its author. Narratives that de-emphasized the author's personal qualities while stressing their internal logic helped Galileo bypass the problems posed by his modest professional and social status. Third, narratives whose acceptance did not appear to hinge on their author's ad herence to specific disciplinary "forms of life" had a better chance to be understood and accepted by Galileo's diverse audiences.

The logic of Galileo's narratives rested on the specificity of his observational protocols. ${ }^{48}$ The production and reproduction of his observations was a timeconsuming process not only in the sense that much labor and effort went into it,

Galileo's stars but rather at his sudden stardom. In September 1610, Magini remarked to Monsignor Benci that, "in some universities, other mathematicians are paid better." For instance, recently Mr. Galilei has received 1000 florins from the Venetians, and is currently retained by the Grand Duke with 1200 scudi for life, although 1 know in my conscience that 1 am not at all inferior to but rather superior to him" (ibid., X:388, 429).

${ }^{47}$ On the transition from this kind of sociabilities to more interdependent ones, see Biagioli 1996a, 193-238.

48 These protocols have been discussed, in various degrees of depth, in Drake 1979, 75-95; van Helden 1989, 10-6; Chalmers 1990, 54-5; and Dear 1995, 107-11. What, in my view, has not been previously addressed is how Galileo's observational practices dovetailed with his concerns about minimizing disclosure and maximizing credit. 
but, more importantly, in the sense that the evidence behind those discoveries was inherently historical. Like other astronomical phenomena, the satellites of Jupiter were observed as a process (and, I argue, were probably observable only as a process).

One does not see the precession of the equinoxes by looking in the direction of the celestial pole for a few hours but detects it by comparing and interpolating the observations of the motion of the celestial pole through the stars over centuries. Similarly, one did not "see" the satellites of Jupiter just by pointing the telescope toward that planet for a few minutes. That would have shown, at best, a few bright dots. What enabled their discovery was not a specific gestalt that immediately turned those dots into satellites, but a commitment to produce the suitable apparatus and conduct observations over several days so as to detect the periodic motions of the satellites and differentiate them from other visual patterns (be they fixed stars or optical artifacts produced by the instrument). Because of the features of early telescopes (narrow field of vision, double images, color fringes, and blurred images especially toward the periphery), people who looked through a telescope for only a few minutes could legitimately believe that Galileo's claims were artifactual, as numerous spurious objects could be seen through a telescope's eyepiece at any given time.

This view of Galileo's process of discovery is no a posteriori reconstruction but conforms to his log entries, to the Nuncius, and to a letter written immediately after his first observation of Jupiter. When he observed Jupiter for the first time on January 7,1610 , Galileo wrote to a friend that he had seen three fixed stars near the planet, two to the east and one to the west (Galilei, 1890-1909, X:259, 277). In the Nuncius he added that these stars seemed "brighter than others of equal size" and "appeared to be arranged exactly along a straight line and parallel to the ecliptic" but, in and of itself, their peculiar appearance and arrangement did not cause him to doubt that they were fixed stars (Galilei 1989, 64).49 At first, he "was not in the least concerned with their distances from Jupiter," but on the following night he noticed that while the three stars had remained close to the planet, they had all moved to the west (ibid., 65). Even then, Galileo did not think that the stars had shifted. ${ }^{50} \mathrm{He}$ assumed, instead, that Jupiter must have moved (though he was puzzled by the fact that, according to his tables, it should have gone in the opposite direction) (ibid., 65). Clouds prevented him from observing on the following night. On January 10 , however, he was surprised to see that only two stars were visible and that they had again switched sides, this time from the west to the east (ibid., 65-6). He could make sense of the missing star by thinking that it must have been

\footnotetext{
49 In the January letter he had already remarked that planets appeared well demarcated ("like small full moons") when observed through the telescope, but that fixed stars remained so shimmering that their shape could not be detected. It seems, therefore, that the three "fixed stars" around Jupiter had struck him as being of the size of stars while looking more like planets.

so "at this point I had by no means turned my thought to the mutual motions of these stars"(Galilei $1989,65)$.
} 
hidden by Jupiter, but could not believe that Jupiter had moved around again (ibid., 66). On January 11, there were still only two stars to the east of Jupiter, but they had moved much further to the east of the planet, were closer to each other, and one of them appeared much larger (though on the previous night they had appeared to be of equal size). Only at that point did he conclude that what he had observed were not fixed stars but planets (stelle erranti) and that "they had been invisible to everyone until now" (Galilei 1890-1909, III, Part 2:427; Galilei 1989, 66). Both the Nuncius and his log show that from that night on Galileo began to record the changing distances between them and Jupiter, having probably decided that the robustness of his claims rested on the determination of their motions (Galilei 1890-1909, III, Part 2:427). ${ }^{51}$ On January 13, after having sturdied the telescope's mount, he observed a fourth satellite. ${ }^{52}$ Since January 15 , all his $\log$ entries were made in Latin, suggesting that on that date he decided to publish the Nuncius and to include the daily positions of the satellites in it (ibid.).

To Galileo, then, the evidence that counted was not a snapshot of individual luminous dots around Jupiter, but the "movie" of their motions (Galilei 1989, 67-83). It was "historical logic" that linked his string of observations and turned the luminous bodies near Jupiter into satellites, not fixed stars. Since the title page of the Nuncius, in fact, Galileo identified the satellites with their motions - "four planets flying around the star of Jupiter at unequal intervals and periods with wonderful swiftness" - a characterization that was then repeated in the text (Galileo 1989, 26, 36).

The Nuncius' mapping of the satellites' motions did not stop on January 13, but continued with painstaking descriptions of more than sixty configurations (which he also represented as diagrams) of the four satellites over forty-four almost consecutive nights (fig. 2). The textual and diagrammatic description of their movements occupies a large portion (about 40 per cent) of Galileo's text. Taken at face value, this section may appear tedious (Drake's first English translation edited out most of it) as it does not present complex arguments or exciting evidence. ${ }^{53}$ And yet, Galileo included it and continued to observe the satellites for several more weeks despite being already certain of his claims and despite his fear that any delay in publication could deprive him of priority. His actions clearly indicate the importance he placed on this section - a section he then planned to expand in a revised edition of the Nuncius (Galilei 1890-1909, X:332, 373). ${ }^{54}$ Although after

si In the Nuncius he added that the procedure he followed to measure these distances was the one described at the beginning of the book (Galilei 1989, 66). On Galileo's shift from fixed stars to planets, see also Drake 1976a, 153-168. For a reconstruction of the visibility of Jupiter's satellites in the period Galileo first observed them (and what he may have missed because of the quality of his telescope), see Meeus 1964, 105-6.

67).

52 "Havendo benissimo fermato lo strumento" (Galilei 1890-1909, III, Part 2:427; Galileo 1989,

53 In Galilei 1957, Drake edited out all the observations from January 14 to February 25.

54 Such an edition, however, never materialized. The last observation of the satellites reported in the Nuncius is from March 2, and the book was off the press on March 13. The lunar observations included in the Nuncius, instead, dated from much earlier. According to Ewan Whitaker's reconstruc- 


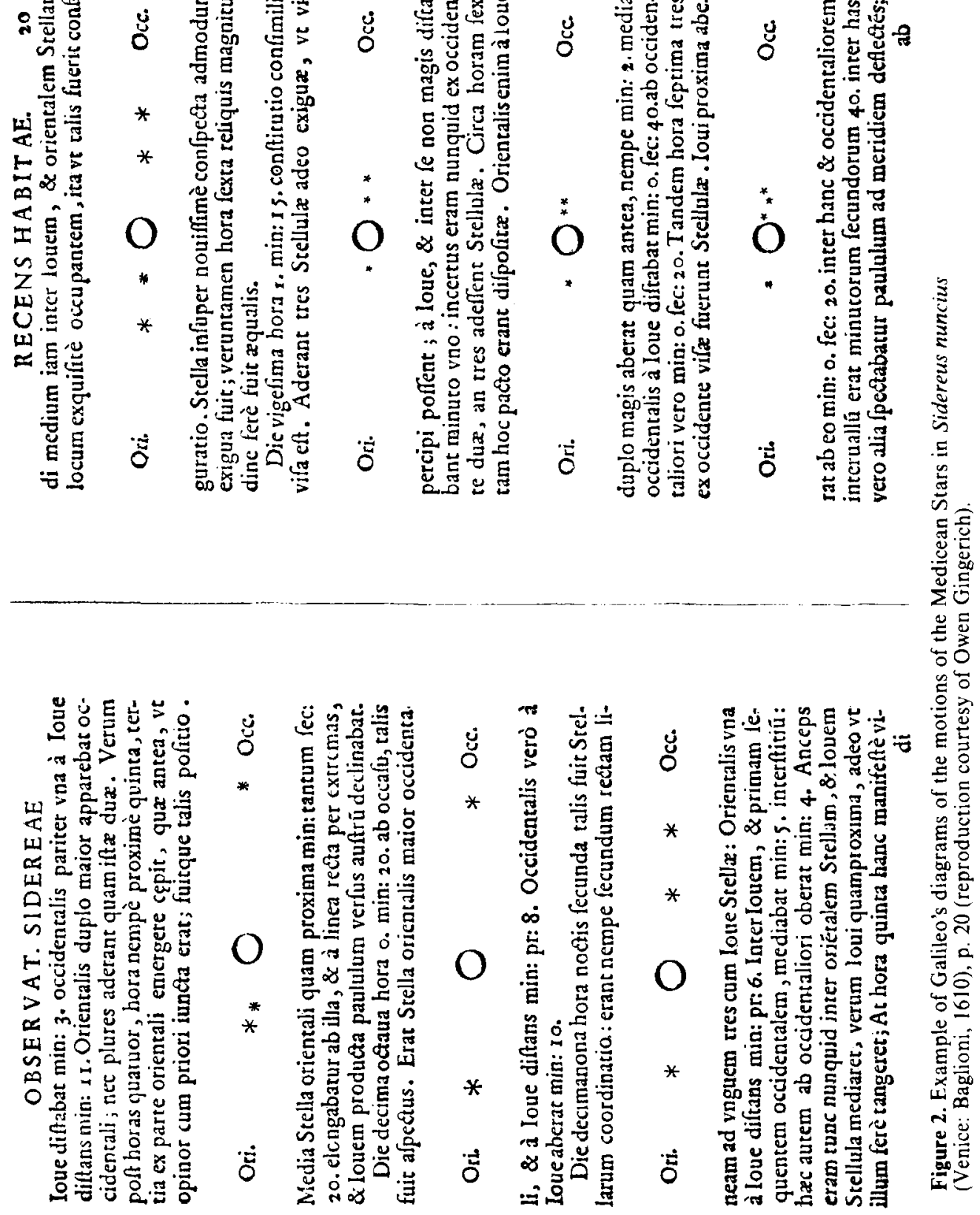


the publication of the Nuncius he refrained from giving telescopes to other astronomers, he sent them records of his continued observations (Galilei 1890-1909, X:362, 403). In fact, if one trusted Galileo's description of their rapid movements (and that such movements seemed to lie within a specific plane), it would have been difficult to claim that the satellites were optical artifacts produced by the telescope. The determination of the satellites' periods would have provided even stronger evidence for the Stars' existence, but a preliminary mapping of the luminous dots' regular motions along a plane already cast them as strong candidates for physical phenomena.

Interesting, the only feature of the telescope Galileo discussed at some length at the beginning of the Nuncius was not its construction and optical principles, but its use for measuring angular distances, that is, for tracking the movements of the satellites and detecting their periods (Galilei 1989, 38-9). And Galileo's exhortation to his colleagues to go beyond what he had done only concerned the periods of objects he had already detected, not new discoveries. Read in the context of his monopolistic ambitions, his saying: "I call on all astronomers to devote themselves to investigating and determining their periods" does not sound like an altruistic tip, but an attempt to channel his competitors' drive in directions useful to him. Even if they preceded him at determining the periods, their confirmation of the physical reality of the satellites would have still helped him. Similarly, the "virtual witnessing" which the Nuncius offered to those readers who did not have telescopes was part of a strategy of control, not of collaboration or community-building (Shapin 1984, 81-520; Shapin and Schaffer 1985, ch. 2). His reports were not aimed at facilitating independent replications, but at satisfying his readers with narrative simulations of his own experience so that they would not feel the need to pursue it on their own. He cast his readers not as colleagues in an emerging philosophical community, but as remote, credit-giving consumers.

Galileo used the same "historical" logic of observation to argue that, contrary to received views, the lunar surface was not smooth but rugged like the earth's $\left(\right.$ Galilei 1989, 40). ${ }^{55} \mathrm{He}$ also adopted such an approach a few years later in his book on sunspots which was suggestively titled "History and Demonstrations Concerning Sunspots" (Galilei 1613; emphasis mine).

In the Nuncius, he opened his discussion of the moon's appearance with the observation that "when the Moon displays herself to us with brilliant horns, the boundary dividing the bright from the dark part does not form a uniformly oval line, as it would happen in a perfectly spherical solid, but is marked by an uneven, rough, and sinuous line" (Galilei 1989, 40). As with the satellites of Jupiter,

tion of the dating of Galileo's lunar observations and drawing, all but one were done by December 18 (Whitaker 1978, 155-69). His essay also recapitulates the previous debate about the dating of such observations). This shows that from January 7 to March 2 Galileo dedicated himself almost exclusively to observing the satellites to substantiate a claim he was already sure of by January 11 .

${ }_{55}$ See also his description of the lunar surface in the January 7 letter (Galilei 1890-1909, X:259, 273-7) 
Galileo's problem was to show that physical objects (valleys and ridges) were behind the irregular visual appearance of the terminator. And, as with the satellites of Jupiter, his argument did not stop at one snapshot of the irregular pattern of bright and dark spots on the lunar surface but continued with a discussion of how that visual pattern changed in time:

Not only are the boundaries between light and dark on the Moon perceived to be uneven and sinuous, but, what causes even greater wonder is that very many bright points appear within the dark part of the Moon, entirely separated and removed from the illuminated region and located no small distance from it. Gradually, after a small period of time, these are increased in size and brightness. Indeed after 2 or 3 hours they are joined with the rest of the bright part, which has now become larger. In the meantime, more and more bright points light up, as if they were sprouting, in the dark part, grow, and are connected at length with that bright surface as it extends farther in this direction. (Galilei 1989, 42)

He then repeated this same kind of "historical" analysis for specific and particularly conspicuous dark and bright spots, showing how their changing appearances were consistently connected to the changing angle at which sunlight struck the lunar surface as the Moon went through its phases. He also set up a sort of "crucial experiment" by showing the moon at first and second quadrature, that is, when the moon is half full but its bright and dark sides are switched around (fig. 3). By doing so, he tried to show how the irregular patterns of lights and shadows are inverted in the two cases and that, therefore, they constituted the negative and positive picture of the same physical features of the lunar surface.

As in his discussion of the movements of the satellites of Jupiter, Galileo used pictorial representations to guide his readers through the changing patterns of lunar lights and shadows, though in this case the movie was quite "jumpy" and most of the narrative burden was put on the text (fig. 4). ${ }^{56}$ The argument's logic, however, was the same in both cases. The existence of lunar valleys and mountains did not hinge on a few disjointed observations, but on the pattern traced by dark and bright spots as they changed through several interrelated observations (Van Helden 1989, 21-2). Being consistently connected to the phases of the Moon, these changing visual patterns could not be easily dismissed as optical artifacts produced by the telescope (Galilei 1989, 44-5). ${ }^{57}$ Therefore, while having the appearance of

56 For a discussion of the relationship between Galileo's somewhat crude pictures of the moon and his more accurate narrative, see van Helden and Winkler 1992, 207-9. Galileo was aware that the copper plates used in the Nuncius were not as good as they could be and planned to include better illustrations of the moon in a revised edition that, however, never appeared (Galilei 1890-1909, $\mathrm{X}: 332,373$ ).

57 A few years later, during the debate with the Jesuit mathematician Christoph Scheiner on the discovery and nature of sunspots, Galileo resorted again to periodic evidence, not snapshots. His claims about the status of sunspots as objects were inseparable from the description of their periodical movements and of how their shape changed in time. Tellingly, the title of his book was History and Demonstrations about Sunspots. 


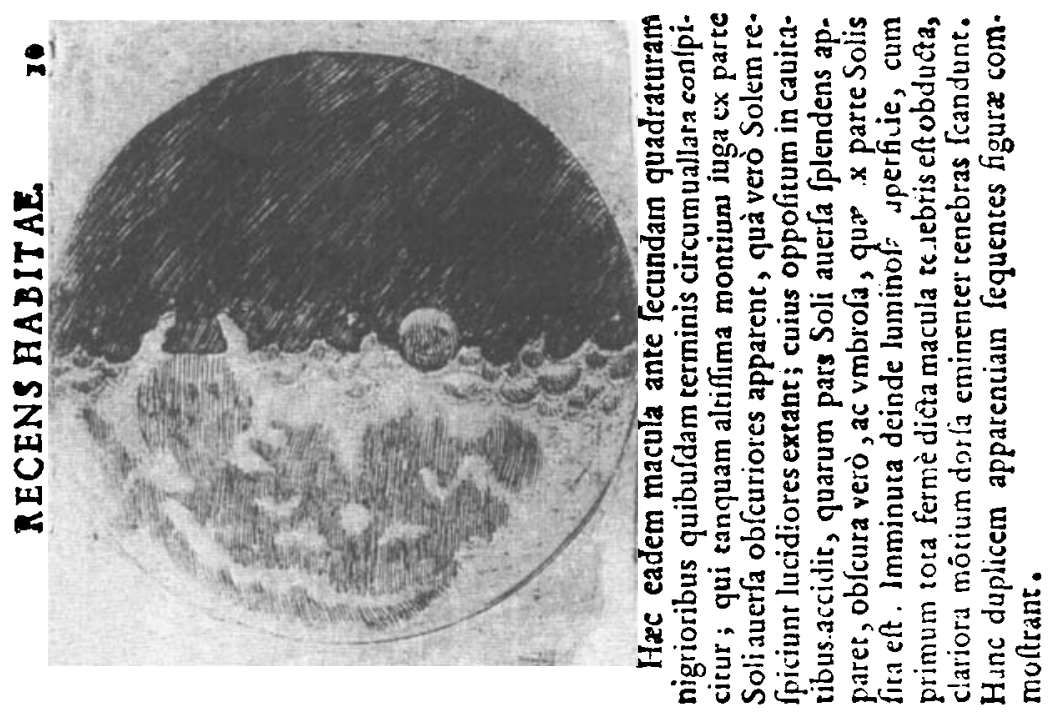

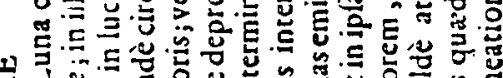

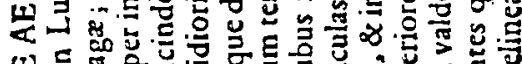

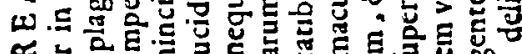

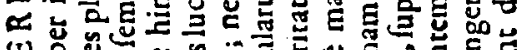

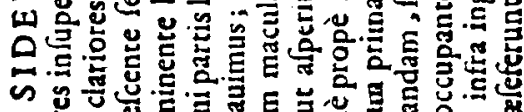

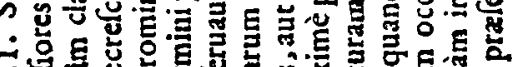

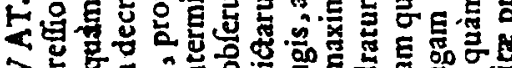

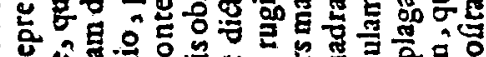

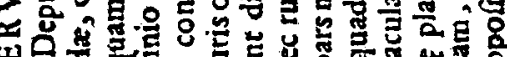

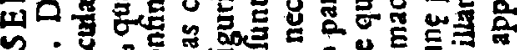

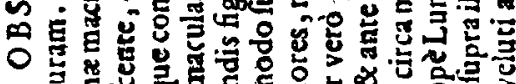

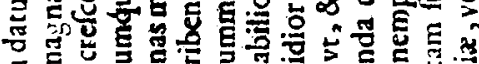

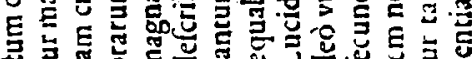

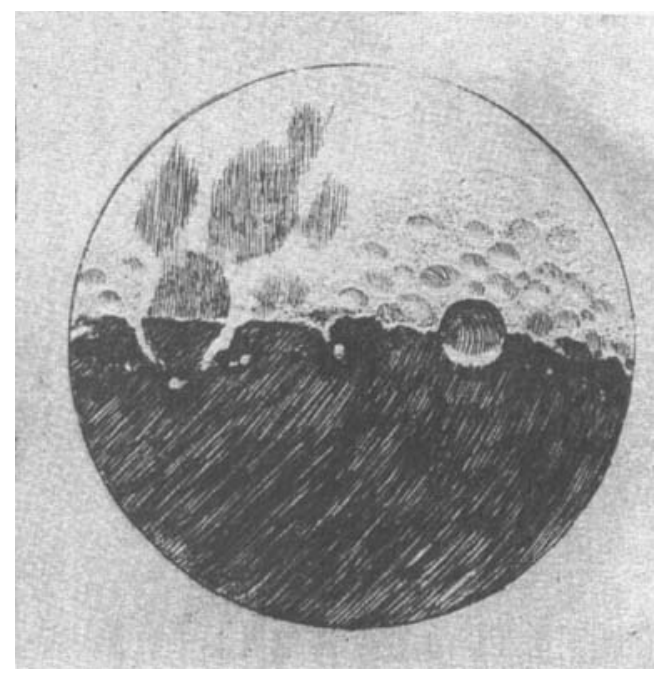

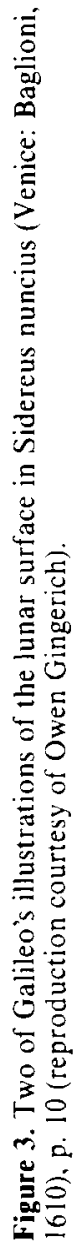




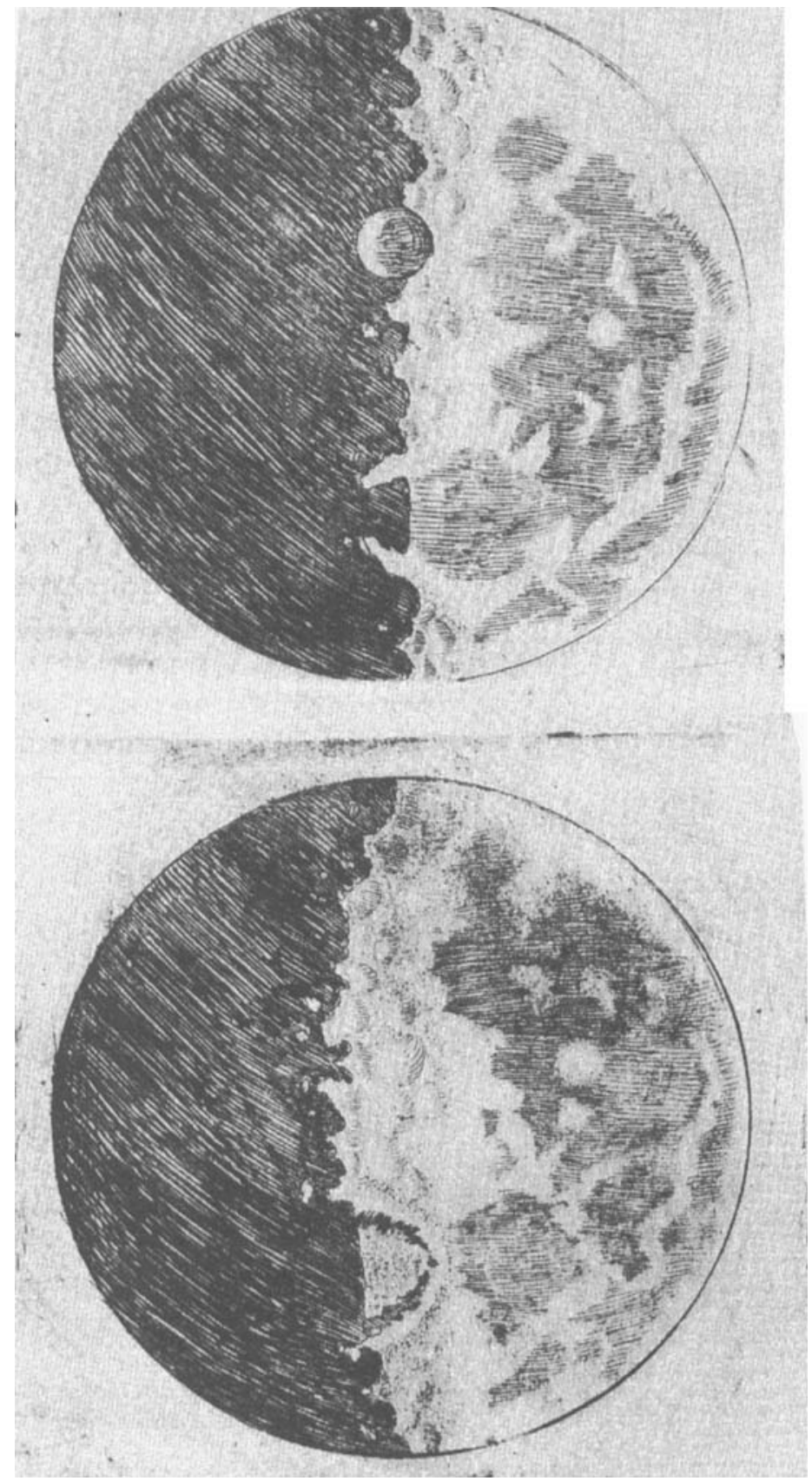

Figure 4. Additional illustrations of the lunar surface in Sidereus nuncius (Venice: Baglioni, 1610), p. 11 (reproduction courtesy of Owen Gingerich). 
"natural histories" of satellites or lunar peaks and valleys, the structure of Galileo's arguments resembled that of demonstrations. They were not syllogistic demonstrations (and they used qualitative representations, not numerical entities or logical categories) and yet they explained effects from physical causes.

However, even those willing to accept that such visual patterns were not artifactual did not need to agree that they were about ridges and valleys. They may have been a movie, but a movie about what? Throughout the discussion of the changing visual appearance of the moon during its phases, Galileo made repeated analogies to how terrestrial mountains and valleys are variously illuminated and cast shadows during the day. The analogy may be read as an anti-Aristotelian argument because it simultaneously undermined the unique status of the earth while claiming that the Moon was not as pristine as the philosophers expected it to be. I believe Galileo would have not opposed such a reading of his argument. However, there was a more specific, local role for the earth-moon analogy in the Nuncius.

In the case of the satellites of Jupiter, Galileo argued that they were real because they had periodical motions, but did not need to convince anyone that planets (the category in which he placed the Stars) had periods. The case of the lunar valleys and mountains, however, was different. While he needed to hinge their physical status on the periodicity of their appearances, here he did not have an astronomical exemplar for that kind of "movie." Terrestrial mountains and valleys provided him with that exemplar. Once Galileo's claims about the ruggedness of the Moon had been accepted, their implications reverberated back on the cosmological status of the Earth, but in the writing of the Nuncius Galileo needed to turn the inferential arrow in the other direction: he needed a messy Earth to show that he was telling the truth about the Moon.

While I do not argue that everyone should have felt compelled to accept Galileo's logic, there was nothing revolutionary about the protocols and inferences he asked his readers to follow. The way he processed telescopic evidence to argue for the existence of the satellites of Jupiter or for the irregularity of the lunar surface was the same used by traditional astronomers to detect the precession of the equinoxes or other time-based phenomena (with the important difference that, in this case, the periods involved were in the order of days, not centuries). The Nuncius' crucial novelty as a narrative was that it translated these practices from a series of numerical observations into a form that could be appealing to the philosophically curious, not only to professional astronomers. Although Galileo made his inferences from geometrical entities (the angular distances of the satellites from Jupiter, the relation between lunar shadows and the height of lunar mountains, etc.) he presented his claims in visual terms - as movies about satellites and shadows. Judging from how few people rejected the Nuncius, it appears that its narratives succeeded at least in casting Galileo's claims as plausible. 


\section{Time and Its Markets}

The few practitioners who, after reading the Nuncius, went on to observe the satellites of Jupiter did adopt the observational practices Galileo had laid out in his text. For example, Kepler and the Roman Jesuits confirmed Galileo's claims after conducting a series of interrelated observations of the Medicean Stars. ${ }^{58}$ The Jesuits remained doubtful about the reality of the satellites after observing them for a few nights, but their skepticism gave way after conducting daily observations over two weeks and noticing their revolutions. ${ }^{59}$ As Clavius wrote on December 17: "Here in Rome we have seen them [the Medicean Stars]. I will attach some diagrams at the end of this letter from which one can see most clearly that they are not fixed stars, but errant ones, as they change their position in relation to Jupiter" (Galilei 1890-1909, X:391, 484).

Analogously, on October 9, Santini wrote Galileo that he had seen the satellites again, "several times, in different positions, so that 1 have no doubt [about their existence]"(Galilei 1890-1909, X:407, 445). In May 1611, Luca Valerio, a Roman mathematician, added a more explicit methodological spin to these remarks:

It has never crossed my mind that the same glass [always] aimed in the same fashion toward the same star [Jupiter] could make it appear in the same place, surrounded by fours stars which always accompany it ... in a fashion that one evening they might appear, as I have seen them, three to the west and one to the east [of Jupiter], and other times in very different positions, because the principles of logic do not allow for a specific, finite cause [the telescope] to produce different effects when [the cause] does not change but remains the same and maintains the same location and orientation. (Favaro $1983,1: 573)^{60}$

While we have much evidence about the importance of time in the corroboration of Galileo's observations, we have no indications that tacit, cosmologicallyinformed perceptual gestalts played a role in that process. Both Galileo and Kepler were Copernicans, but the Jesuits were not (though they were growing increasingly skeptical about the Ptolemaic system). There is no clear evidence about Santini's cosmological belıefs, but none of his letters addressed those issues thus suggesting that he was not particularly concerned with the discoveries' cosmological implications. Cosmological beliefs, it seems, motivated the observers' behavior but did

s8 The structure of Kepler's Narratio resembled that of the Nuncius. In it, Kepler listed daily observations of the satellites of Jupiter from August 30 to September 9 (Kepler 1606, 319-322). Right after the last entry Kepler simply wrote that these observations confirmed Galileo's claims and that he returned the telescope to the Elector of Cologne.

59 The Jesuits' observational $\log$ shows that they had been recording the daily positions of the satellites since November 28 (Galilei 1890-1909, III, Part 2:863).

${ }_{60}$ A similar point is made, in a more humorous fashion, by Galileo in a May $2 \mathrm{I}, 161 \mathrm{l}$, letter to Piero Dini in which he promises 10,000 scudi to whomever can construct a telescope that shows satellites around one planet but not others (Galilei 1890-1909, XI:532, 107). 
not frame their perceptions. ${ }^{61}$ Those who observed the satellites had to invest weeks and months in the project, and did so because they had something to gain (or at least nothing to lose) from corroborating Galileo's claims.

Symmetrically, the rejection of these discoveries did not result from cosmological or perceptual incommensurabilities or from the lack of a satisfactory description of the telescope's workings. Simply, those who opposed Galileo's claims did not take sufficient time to conduct long-term observations. By observing for only a short time, they could plausibly argue that the evidence available to them was, at best, insufficient. And because of the structure of the field, there were no shared professional norms that compelled Galileo's opponents to abide by his rules and invest time and resources to engage in the long-term observations needed to test his assertions, or to require Galileo to give them telescope-time, telescopes, or instructions about how to build them. Galileo's monopolistic attitudes were as ethical or unethical as his critics' allegedly stubborn or obscurantist dismissals.

In the case of the philosopher Cremonini, geocentric beliefs translated into an absolute refusal to observe. It was reported that he did not want to look through the telescope fearing it would give him a headache. ${ }^{62}$ However, it is not that Cremonini was unable to see the satellites of Jupiter because he was an Aristotelian, but simply that such an observation would have been a very unwise investment of time and resources for someone of his disciplinary affiliation and professional identity. Cremonini was not being unreasonable; he simply did not wish to commit professional suicide.

Unlike Cremonini, other critics did look through the telescope, though only for a short time. Because of the brevity of their observations, they remained vocally skeptical about Galileo's reading of those changing patterns of bright spots as satellites. In a letter sent to Kepler right after Galileo's visit to Bologna, Horky wrote that the instrument worked wonderfully when aimed at terrestrial objects but performed poorly when pointed at the sky. Horky was probably correct saying that fixed stars appeared double, a fact that may have made him justifiably skeptical about Galileo's other claims (Galilei 1890-1909, X:301, 343). But while he did not share Galileo's perception of the significance of those spots, he did see them nevertheless. A few weeks later, in the Peregrinatio contra nuncium sidereum, Horky added that when he tried to observe Jupiter he saw "two globes or rather two very minute spots" near Jupiter on April 24, and detected "all four very small spots" on April 25. ${ }^{63} \mathrm{He}$ did not believe that those spots were satellites and yet the

61 Valerio's case is more ambiguous because a few years after he wrote the letter I cited, his membership in the Accademia dei Lincei was suspended when he declined to endorse the Academy's full support of Galileo's pro-Copernican position in the "Letter to the Grand Duchess." However, Valerio's stance in 1615 was not informed by direct geocentric commitments, but rather from the desire to stay out of dangerous cosmological debates. On this dispute, see Biagioli 1995, 139-66.

62 On Cremonini's refusal to confront Galileo's discoveries see Galilei 1890-1909, XI:526, 100 and especially XI:564, 165 .

63 "24 Aprilis nocte sequente vidi duos solummodo globulos aut potius maculas minutissimas". When Horky asked Galileo why the two other two stars were not visible despite the fact that the night 
fact that Galileo's own records for those two nights report exactly the same configurations shows that Horky's cosmological beliefs did not prevent him from registering the phenomena as Galileo saw them (fig. 5). ${ }^{64}$

Giovanni Magini was another of Galileo's early opponents. A professor of mathematics at Bologna, a supporter of geocentric astronomy, and Horky's employer, Magini was among those who spent two nights observing with Galileo. He did not publish a critique of his claims but worked hard at undermining Galileo's credibility through letters describing his fiasco (Galilei 1890-1909, X:303, $345 ; 324,365)$. However, when he described those events to Kepler a few weeks later, Magini adopted a much more accommodating stance, simply saying that those who observed with Galileo at Bologna were unable to see the satellites perfectly (ibid. X:315, 359).
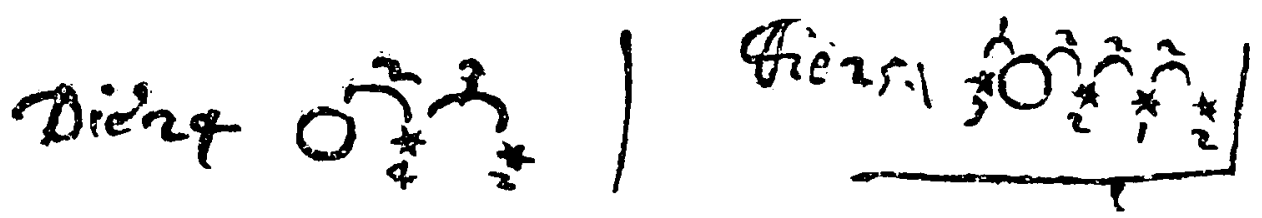

Figure 5. Entries for April 24 and 25 in Galileo's observational log (from Galilei 1890-1909, III, Pt.2, p. 436).

Magini had a point. He and Horky had reasonable grounds for skepticism (such as the double images produced by the telescope) and little incentive to take time to observe. Furthermore, Galileo did little to change their minds. First of all, he did not visit Bologna on the way to Florence (although it was there that a Medici carriage picked him up), but only on the way back to Padua, after he had shown the Stars to the grand duke and his family. ${ }^{65}$ Eager to reach Florence as soon as possible, he actually changed his travel plans and skipped the stopover in Bologna altogether. ${ }^{66}$ Furthermore, his one visit was very short and yielded only two

was clear, he allegedly received no answer (Galilei 1890-1909, IIl, Part 1:140). The next night, "Iupiter occidentalem exhibuerat, cum omnibus suis novis quator famulis supra nostrum Bononiensem Horizontem apparuit. Vidi omnes quator maculas minutissimas a Iove presilientes cum ipsius Galileo perspicillo, cum quo illas se invenisse gloriatur" (ibid., 141). Interestingly, Horky did not admit to having seen any of these "spots" in the April 27 letter to Kepler.

64 Galileo's manuscript log in (Galilei 1890-1909, III, part 1:436), last line. Kepler too spotted the congruence between Horky's report and the configurations of the satellites he had received from Galileo (Galilei 1890 X:374, 416).

65 That Galileo stopped to observe in Bologna on his way to Florence is a claim commonly found in the secondary literature, but is not supported by any evidence contained in Galileo's correspondence or observational log. On March 13, Galileo asked Vinta to send a carriage to Bologna "on the Monday of the week of Passion," that is, the week leading to Easter (Galilei 1890 - 1909, X:271, 289). Other letters confirm the appointment (Galilei 1890-1909, X:278, 303;284, 307). In the Gregorian calendar, Easter fell on April 11, 1610. This means that the previous Friday was April 2, and that Monday of Easter week was April 5. I thank Owen Gingerich (and his remarkable collection of historical ephemerides) for providing the date of Easter 1610.

66 Galileo's observational log shows that on the night of April 2 he was already close to Bologna (he 
observational sessions. A few more nights could have made the satellites'periodic behavior more evident. But on April 26, a few hours after the end of the second session, Galileo left. Horky assumed that Galileo, demoralized by his failure, had left early in the morning to avoid further confrontations with his critics. ${ }^{67}$ Instead, he simply needed to rush back to Padua to teach. In a March 13 letter to the Medici secretary, Galileo stated that the Easter recess at Padua lasted about 23 or 24 days and that he could leave only on April 2 (probably at the very beginning of the vacation) (Galilei 1890-1909, X:271, 289). This suggests that the recess ended on Monday April 26, the day Galileo left Bologna for Padua. He was cutting it quite close. But if he had strong reasons not to delay the departure any further, there is no evidence that he could not have arrived in Bologna a few days earlier. ${ }^{68} \mathrm{He}$ spent almost three weeks in Tuscany, but dedicated only two days to Bologna. Although he may have regretted his rush later, after realizing the harm done by Horky's and Magini's opposition, at that point Galileo seemed content with having shown the satellites to the grand duke and treated the assent of his "colleagues" in Bologna as a side dish that was not worth shortening his Tuscan stay by a few days.

\section{Black-Boxes and Wrapping}

If Galileo's observations did not require revolutionary gestalt switches, neither did their stabilization hinge on blackboxing his tacit instrument-making skills. Others were able to develop those skills in a matter of months without Galileo's instructions, thus suggesting that the "secret" of his telescope was only a trade secret. If one shared Valerio's conclusion (as Clavius, Santini, and Kepler did) that the satellites of Jupiter could not be dismissed as optical artifacts (because, under ceteris paribus conditions, one would expect telescopic artifacts to have a fixed appearance, not orderly motions), then one could consider the telescope's status as unproblematic despite the fact that no one, including Galileo, seemed able to provide a comprehensive explanation of how it worked.

Many studies of experimental replications use the notion of "blackbox." As a topos, the blackbox is usually conceived of as a container filled with some

observed in Firenzuola), suggesting he may have left Padua on April 1. On the 3rd he was already observing in Florence, indicating that he did not stop in Bologna and did not catch the Medici carriage that was supposed to pick him up on the 5 th. On the 5 th, in fact, he was already at San Romano, on the way to Pisa to meet the grand duke (Galilei 1890-1909, III, Part 1:436).

67 "Galileo became silent, and on the twenty-sixth, a Monday, dejected, he took his leave from Mr. Magini very early in the morning. And he gave us no thanks for the favors and the many thoughts, because, full of himself, he hawked a fable. Mr. Magini provided Galileo with distinguished company, both splendid and delightful. Thus the wretched Galileo left Bologna with his spyglass on the twenty-sixth"(Horky to Kepler, April 27, 1610, [Galilei 1890-1909, X:301, 343]). English translation by Albert van Helden in Galilei 1989, 93.

68 He probably arrived in Bologna on either the $23 \mathrm{rd}$ or the $24 \mathrm{th}$, as he was still in Florence on April 20 (Galilei 1890-1909, X:299, 341), but was gone by April 24 (ibid., 300, 341). 
knowledge that was initially tacit, private, and body-bound but was later rendered public, standardized, and (temporarily) unquestioned. The notion of blackbox. however, does not capture the process through which telescopic evidence was accepted. The telescope was neither inherently transparent (as Drake seemed to think) nor was it blackboxed at a later time (as the constructivists would assume). While philosophically opposite, these two positions share the assumption that legitimation is always needed and that it comes from some kind of knowledge that answers possible de-legitimizing doubts about the instrument's epistemological status (though the two camps would disagree on whether such knowledge is explicit or tacit, in the mind or in the body, about instruments or about the social qualifications of the people who use them). Instead, I argue that the telescope could be treated (or rather ignored) as a non-problem. What mattered was not the contents of the blackbox but its wrapping, that is, the narratives within which Galileo structured his reports.

Similar considerations apply to the status of Galileo the observer. The narrative logic of the Nuncius not only reduced the pressure on Galileo to disclose the workings and manufacture of the telescope, but it also cast his personal trustworthiness as something of a non-question. Although readers of the Nuncius were asked to believe Galileo's claims about spending several nights on the roof of his house observing the changing positions of the satellites of Jupiter or the changing appearances of the moon, they were not required to trust the accuracy of all the specific observations he reported. Because Galileo's claims were about the recursiveness of certain patterns, their robustness did not rely on one crucial observation or experiment, nor did it hinge completely on his personal qualifications as a trustworthy observer. ${ }^{69}$

\section{Inventions and Disclosure}

Before 1610, Galileo participated in various professional and social groups which, in different ways, accustomed him to the value of limited disclosure and to the appreciation of economies of reward based on local patronage. He was by no means a reclusive scholar and yet he seemed quite content to limit his audience to the circles of Paduan academics, Venetian patricians, and Florentine courtiers with whom he discussed philosophy, music, mathematics, and literature. ${ }^{70} \mathrm{He}$ also

\footnotetext{
69 Also, unlike later seminal texts of experimental philosophy, the Nuncius was not cast as the exemplar of a philosophical "form of life." Galileo tried to blackbox neither the telescope nor the community of its users. He adopted the customary protocols of long-term observational astronomy, but did not treat other astronomers as colleagues. The Nuncius tried to get credit from whatever constituency it could reach, and it did so by minimizing (not maximizing) the role of social conventions and values of any given community.

70 Although he was forty-six by the time he wrote the Nuncius, Galileo had made no prior attempts to reach broader readerships through his publications, and his correspondence had been modest in volume and geographically limited to Italy. Even Kepler's 1597 invitation to engage in an epistolary dialogue about Copernicanism did not move him (Galilei 1890-1909, X:59, 69-71).
} 
interacted actively with "low-culture" practitioners: artists, artisans, and engineers. Until 1610 , the only publication under his name was a short instruction manual of a military compass - a device he developed and then sold privately to his students. ${ }^{71}$

Placed in this context, the monopolistic tactics Galileo displayed in the Nuncius and his carefully controlled distribution of telescopes were not just the actions of an author who "held back"; they could be seen also as the behavior of someone who had not "gone out" before and knew little about what to expect from larger audiences. Being new to the business of writing something like the Nuncius, he framed his tactics within the local and non-cooperative credit systems he was familiar with and extended them to cover much wider audiences, but without fully recasting them into a cooperative framework - a framework he had few exemplars for and from which, in any case, he had little to gain.

Some of Galileo's tactics came from his astronomical background, but others came from the world of inventors and instrument makers. He had been designing and producing instruments and machines prior to 1609 , and his career as an inventor peaked precisely with the development of the telescope in the nine months leading to the publication of the Nuncius. Before he realized he could gain more credit for his discoveries than for his instrument, Galileo focused on the telescope as his ticket to success. By March 1610 he had fashioned himself as the discoverer of the Medicean Stars, but just a few months before he was still casting himself as the inventor of the first high-power telescope - an instrument he marketed for its military (not astronomical) applications. Galileo the inventor turned into Galileo the discoverer, but the metamorphosis was never complete.

Many readers seemed to recognize the inventor's "voice" in the Nuncius, as neither supporters nor critics questioned his secretive attitudes on ethical grounds. Some wished he had given out telescopes or information how to build them, but did not expect him to do so - at least not for free. The Elector of Fraising, for instance, read the Nuncius and, disappointed with how little Galileo had shared with his readers about the construction of high-power telescopes, offered him a reward if he communicated his secret to him and promised not to divulge it to others. ${ }^{72}$ Galileo, then, was treated as an artisan entitled to have proprietary attitudes about the "secret" of the device he had developed - an artisan who had met the very low disclosure requirements typical of early modern inventions. ${ }^{73}$ The

71 He was also the probable author of a short 1605 pseudonymous satirical publication that, written in Paduan dialect, was meant for local consumption.

${ }^{72}$ On April 14, 1610, Galileo's brother, Michelangelo Galilei, reported that according to the Elector: "non havendo voi, in questo vost ro primo libro, insegnato chiaramente tal fabbrica, li pare che sia di mancamento; et dice, se metterete innesecuzione quello che scrivete, che vi farete immortale; et vi prega, non volendo voi insegnare a altri detta fabbrica, al manco siate contento di volerne compiacere S.A., che vi si dimostrerà quel principe che egli e"(Galilei 1890-1909, X:290, 313).

${ }^{73}$ Later, on January 7, 161 1, Mark Welser wrote Galileo that "I can tell you that information about how to build [telescopes] is much desired here [in Germany]," but did not intimate that Galileo's secrecy was seen as unethical (Galilei 1890-1909, XI:452, 14). 
word "secreto" appeared often in correspondence discussing early telescopes, thus confirming that most of Galileo's contemporaries had a clear sense of the economy in which these instruments circulated.

There was no international patent law in Galileo's time. The protection of inventions depended on local legal and administrative practices, and was necessarily limited to the state that issued it. ${ }^{74}$ Typically, the inventor was expected to show the appropriate officials a working example of the device for which he sought a temporary monopoly within that state's jurisdiction, but did not need to provide a full description of that device. ${ }^{75}$ For instance, a north-European artisan approached the Venetian Senate in August 1609 asking for one thousand ducats for a low-power telescope, but did not want the Venetian authorities to examine the instrument, but only to look through it. ${ }^{76}$ Paolo Sarpi, acting as the Senate's advisor, opposed the offer but not because he thought that the inventor's position was unethical. ${ }^{77}$ What he objected to was the high price the artisan demanded for an instrument whose "secret" was proving to have a remarkable short half-life. Similarly, disclosure was not mentioned in any of the documents related to Hans Lipperhey's October 1608 application for a patent for the telescope he filed in the Netherlands (Van Helden 1977, 36-44).

If disclosure requirements were a local matter, so was the definition of inventor. ${ }^{78}$ If local authorities deemed a certain device useful or protectable (or both), they

74 According to Christine McLeod, Italian states had been at the forefront of the development of property rights for technical achievements, and these legal and administrative models were then transferred to northern Europe and England. In particular, Venice "was the first to regularize in law the award of monopoly patents, the Senate ruling of 1474 that inventions should be registered when perfected: the inventor thereby secured sole benefit for ten years, with a penalty of 100 ducats for infringement, while the government reserved the right to appropriate registered inventions. "In order to expand the geographical coverage of their patents, inventors registered them in other states, provided they were deemed interesting enough to deserve that treatment (McLeod 1988, 11).

75 In England, for instance, the legal demand for written specifications emerged only in the early eighteenth century, and such specifications were made public only towards the end of the century (MacLeod 1988, 11-2). Before then, "It was rare to demand anything of the patentee" (ibid., 13).

76 On August 22, 1609, Giovanni Bartoli, the Medici agent in Venice, wrote to Florence about a foreign artisan's offer of a telescope to the Senate, and that the instrument was tried out from St. Mark's bell-tower (like Galileo's a few days later), but that many thought that its "secret" was well known in France and elsewhere, and that similar instruments were quite cheap outside Venice (Galilei $1890-1909, X: 227,250$ ). The reference to the foreign artisan not allowing any internal inspection of the telescope is found in Drake 1978, 140, and in Drake 1970, 147-8. Drake cites no sources, but his description of the glassmaker's actions matches standard artisanal practices. MacLeod argues that in sixteenth-century England, an inventor was not required to share his secret if the technology he was bringing into the country helped the "furtherance of trade" (MacLeod 1988, 13).

77 Sarpi may have done some "technology transfer" here. On August 29, 1609, Bartoli wrote to the Medici secretary that Sarpi told Galileo about "the secret he had seen [the foreigner's telescope]" and that Galileo, moving from that tip was able to produce a better instrument (Galilei 1890-1909, X:233, 255). Given Sarpi's role in the Venetian government, it would have been quite ethical for him to facilitate Galileo's successful development of the telescope by feeding him information that could lead to a better instrument (and then to see it accepted and rewarded by the Senate).

${ }_{78}$ Such a definition of inventor makes sense in a context in which many inventors were itinerant artisans making a living out of spreading a country's technology into another (very much like the foreigner who first brought the telescope to Venice). In sixteenth-century England, "the rights of the first inventor were understood to derive from those of the first importer of the invention" (MacLeod $1988,13)$. Such a definition was still held in the early seventeenth century (ibid., 18). 
might issue a privilege (through a "letter patent") to a person who was not necessarily the original inventor but just the one who made available or perfected that technology within the jurisdiction of the privilege-granting authorities. One could obtain a privilege for the exclusive use of the printing press in Venice for a certain amount of time despite the fact that his name was not Gutenberg. ${ }^{79}$ This, I think, casts interesting light on the debate about whether or not Galileo was the inventor of the telescope (Rosen 1954, 304-12).

Galileo's gift of the telescope to the Venetian Senate in 1609 did not amount to a proper patent application (most likely because he knew that such a privilege would have been unenforceable given how widespread telescope-making skills had become). ${ }^{80}$ However, some of his interactions with the Venetian Senate (such as the monopoly he offered them for the use and production of the instrument, and the higher salary and tenure at Padua he received as a counter-gift from the Senate) conformed to artisanal and legal practices according to which he was the inventor of that kind of telescope within the jurisdiction of the Republic of Venice. ${ }^{81}$ Galileo's tactics appear even less remarkable when we realize that some inventors did not request patents but donated their devices to their rulers in exchange for a job or a pension. ${ }^{82}$ Even the patent application for the telescope filed by Hans Lipperhey with the States-General at the Hague on October 4, 1608, asked for an annual pension in case the patent itself were to be denied. ${ }^{83}$ Galileo's gift of the

79 On September 18, 1469, Johannes of Speyer received a privilege from the Collegio of the Signoria for printing in Venice and his dominion for five years (Gerulaitis 1976, 21).

${ }_{80}$ This problem had already caused Lipperhey to have his patent application denied in the Netherlands. On October 14,1608, the States-General commented that "we believe there are others [other inventors] as well and that the art cannot remain secret at any rate, because after it is known that the art exists, attempts will be made to duplicate it, especially after the shape of the tube has been seen, and from it has been surmised to some extent how to go about finding the art with the use of lenses" (van Helden 1977, 38-9). Lipperhey, like Galileo after him, stressed the military application of the telescope.

81 Galileo's dedication of the telescope to the Venetian Doge is not a simple letter, but a formal document that was officially debated and discussed by the Senate. If it did not ask for specific qui pro quo, that was for politeness' sake. The Senate did understand that Galileo was offering them a device (whose military applications were clearly laid out in the letter of presentation) in exchange for a better salary at Padua (which they did give him, together with tenure). Galileo's letter of presentation is in Galilei 1890-1909, X:228, 250-1.

82 Inventors who had developed something directly useful to the state itself (as distinct from a technology that could foster a state's industry and trade) would not usually apply for a patent, especially knowing that states could take over their patents if they wished to do so. On the issue of state appropriation of patents, see the Venetian Senate ruling of 1474 in McLeod 1988, 11.

83 "On the request of Hans Lipperhey, born in Wesel, living in Middelburg, spectacle-maker, having discovered a certain instrument for seeing far, as has been shown to the Gentlemen of the States, requesting that, since the instrument ought not to be made generally known, he be granted a patent for thirty years under which everyone would be forbidden to imitate the instrument, or otherwise, that he be granted a yearly pension for making the said instrument solely for the use of the land, without being allowed to sell it to any foreign kings, monarchs, or potentates; it has been approved that a committee consisting of several men of this assembly will be appointed in order to communicate with the petitioner about his invention, and to ascertain from the same whether he could improve it so that one could look through it with both eyes, and to ascertain from the same with what he will be content, and, upon having heard the answers to these questions, to advise [this body], at which time it will be decided whether the petitioner will be granted a salary or the requested patent" (Van Helden 1977, 36). Notice that the section about the pension matches quite closely what Galileo requested two years later in Venice. 
telescope to the Senate in exchange for tenure and a salary raise fits squarely in this tradition. ${ }^{84}$

The workings of the early privilege system explain not only Galileo's secrecy but also his sense of to whom disclosure was due. As the Venetian Senate was the institutional patron to reward Galileo for his gift of the telescope, it was the Senate (not the readers of the Nuncius or fellow-astronomers) that Galileo felt obliged to share the secret of the telescope with. In fact, the only substantial description of Galileo's instrument (including the focal length of the objective lens, angle of view, and overall size of the instrument) is found in one of Sarpi's private letters. ${ }^{85}$ Sarpi had access to this information because he was the Senate's advisor on telescopes, not only Galileo's close friend. Galileo had the same sense of obligation toward his next patron, the grand duke of Tuscany. In 1610, two months after the publication of the Nuncius, Galileo told Belisario Vinta, the grand duke's secretary: "I do not wish to be forced to show to others the true process for producing [telescopes], except to some Granducal artisan" (Galilei 1890-1909, X:307, 350). Disclosure was given to the source of credit, and in Galileo's social field credit came from patrons, not "colleagues."

There is some irony here. Much of Galileo's career ambitions after 1610 focused on gaining recognition as a philosopher, not a "mere" mathematician or instrument-maker. However, his career as a philosopher hinged on the fact that at that time he was not perceived as a philosopher but as a remarkable instrumentmaker and that, as such, he was entitled to keep his secrets. Such a sociallysanctioned right to secrecy allowed him to develop a monopoly on observational astronomy and obtain the title of "philosopher" he desired so much, despite the fact that secrecy was not exactly a customary value among philosophers.

One could even say that Galileo's secrecy was not a right but a duty. Having been rewarded by the Senate for his telescope, he was obliged not to divulge its secret or

84 Additionally, offering a device to a prince in exchange for a job or a pension made particular sense when such a device had no great commercial potential. In fact, in the summer of 1609 , the telescope had only two financially rewarding applications: gadgets for rich gentleman, or military intelligence. Galileo already knew that the market for "play" telescopes was becoming quickly saturated and that prices were dropping fast. Also, the more telescopes one produced and sold, the more likely it was that his "secret" would be copied. The military market was more appealing. The telescope did have military applications, but one can also speculate that Galileo had plenty of reasons to amplify the range and importance of such applications, as he did in the formal presentation of the instrument to the Venetians. Selling the telescope to a prince was the best deal he could think of under those circumstances. After buying Galileo's device, the Venetians would have had all the interest to keep its secret for as long as possible, thereby lengthening Galileo's leverage. And Galileo could still enjoy tenure and a higher salary after the secret was gone.

85 "Constat, ut scis, instrumentum illud duobus perspicillis (lunettes vos vocat is), sphaeric ambobus, altero superficiei convexae, altero concavae. Convexus accepimus ex sphaera, cuis diameter 6 pedum; concavum, ex alia, cuius diameter latitudine digiti minor. Ex his componitur insrumentum circiter 4 pedum longitudinis, per quod videtur tanta pars objecti, quae, si recta visione inspiceretur, subtenderet scrupula 1.a 6; applicato vero instrumento, videtur sub angulo maiori quam 3 graduum" (Sarpi to Leschassier, March 16, 1610 [Galilei 1890-1909, X:272, 290]). Why Sarpi felt free to share this information with his Parisian friend remains an open question. 
to sell his instruments to anyone other than his employers. ${ }^{86}$ During his flirtation with the Medici, Galileo was treading on delicate grounds as he was enticing a new patron with an instrument for which he had already been rewarded by another patron. ${ }^{87}$ Because the Senate had rewarded the telescope for its military applications, sending an instrument to the Medici might have amounted to treason. ${ }^{88}$ That Galileo kept promising to send the grand duke a good telescope but only took one to Florence himself at Easter time suggests that he probably felt he could not send an instrument to the Medici without violating his contract with the Venetians. ${ }^{89} \mathrm{Had}$ there been an international patent law, Galileo could have been in serious trouble. Instead, he could simply cross the river Po and start a new professional life. ${ }^{90}$

Finally, the conventions of early patents may explain, from another angle, why Galileo never provided a description of the optical processes of image-formation through a telescope. Unlike the historians and philosophers of science who have seen this alleged failure as potentially damaging of the epistemological status of the telescope, Galileo seemed unfazed by it (see for example Machamer 1973, 1-46, esp. 13-27). He did not seem to be familiar with the most relevant optical

86 Unlike what I have written elsewhere (Biagioli 1993, 45-7) the fact that Galileo never sold his instruments was not just a matter of social self-fashioning but also of legal obligations. On October 3 , 1609, Giovanni Bartoli, the Medici representative in Venice, wrote to Florence that Galileo's instruments were the best and that he was building 12 of them for the Senate. However, he continued, Galileo could not teach anyone how to build them because he had been ordered by the Senate not to divulge the secret (Galiliei X:241, 260). Bartoli repeated the point a few days later (ibid., X:242, 260). And if Galileo could not divulge the secret, one can assume he could not sell his instruments either.

87 On June 5, 1610, the Medici promised Galileo that: "in the meantime [your appointment] will be kept as secret as possible" (Galilei 1890-1909, X:327, 369). The Medici resident in Venice wrote to Florence on June 26 that "I have been asked if it is true that Dr. Galilei is going to serve the grand duke with a great salary. I answered I didn't know anything about it. If what they say is true, and is found out, it could give him trouble here" (ibid. X:343, 384)

88 One way to interpret Galileo's behavior is that by the beginning of 1610 everyone understood that the "secret" of the telescope was hopelessly public, and that his contract with the Venetians was therefore more nominal than actual. In any case, it is interesting that Galileo's disclosure of the telescope to the Medici, his proposal to send several of them to European princes, and his acceptance of a contribution toward the cost of producing those instruments came only after both Galileo and the Medici understood that a position for him at the Florentine court was a serious possibility. And the distribution of instruments and the payment of the Medici's contribution took place only after he was told, during his Easter visit to Florence, that his employment in Florence was almost a fait accompli.

89 The Medici seemed to understand that they were in a peculiar position. Around April 1610 , Alfonso Fontanelli, a diplomat from Modena who had observed with Galileo's telescopes (probably at Pisa) told jokingly to the grand duchess that as soon as other nobles heard of the quality of the Medici's instruments, they would flood them with requests. To this, the grand duke and the grand duchess replied that the telescopes they had did in fact belong to the Venetians and that the Medici could not give them to anyone else (Galilei 1890-1909, X:304, 347). However, in that same period, the Medici were also evaluating Galileo's request to distribute telescopes to European princes through their diplomatic networks.

90 We know from Sagredo that Galileo's departure from Venice (and especially the modalities of such departure) had upset several people there. I had previously thought that the Venetians'indignation had to do with what they must have perceived as Galileo's ingratitude (Biagioli 1993, 44-5). In light of this new evidence, the Venetians probably thought that Galileo had behaved unethically, perhaps even illegally. As a thought experiment, it may be interesting to consider what could have happened to Galileo had his new patron been a prince who, unlike the Medici, did not have friendly relations with the republic of Venice. 
literature (Kepler's 1604 Ad Vitellionem paralipomena) nor did he seem anxious to fill his knowledge gap. Years later, he still did not think that Kepler's Dioptrice (a text in which the German mathematician discussed the process of telescopic image-formation) actually shed much light on the workings of the telescope and told Jean Tarde that Kepler's book was so obscure that maybe not even its author had understood it. ${ }^{91}$ But no matter what Galileo's knowledge of optics might have been, he did not need to produce such an explanation.

\section{Inventions, Discoveries, and Natural Monuments}

The Nuncius, however, was not a private letter requesting a privilege from a local political body. Written in Latin and printed in 550 copies, it was aimed at a European audience. It did open with a brief and vague discussion of the telescope, but its stated purpose was to report discoveries. These discoveries, however, were still dedicated to and tailored to the patron, the Medici, who was as local as the patron to whom Galileo had previously offered the telescope. And while the Nuncius made his discoveries public, it did not break Galileo's artisanal secrecy about the telescope (because neither the Medici nor the Venetians wished him to divulge the secret of the instrument).

So, what kind of genre, what kind of economy did the Nuncius belong to? Into what "market category" did the Medicean Stars fall? For one, they were not discoveries in the modern sense of the term. Galileo did not operate in the kind of economy of discoveries that began to develop in the late seventeenth century: the placing of discoveries in the public domain in exchange for professional, nonmonetary credit that accrued on the author's name. Instead, like any other inventor, Galileo received financial rewards from the Medici. At the same time, the Medicean Stars were not inventions to be used locally by a patron and kept secret within his jurisdiction. Their value was predicated on being as widely visible as possible. And while authenticity was not an issue in the economy of early inventions, the Medici did care about the fact that Galileo was the original discoverer of the Stars, not just someone who had "brought them" to Florence.

Indeed, what is worth noting is that the Stars were simultaneously private and public objects. The Medici did not own the Stars the way they could have owned an invention, and yet the Stars did belong to them in some ways. Galileo presented them simultaneously as natural entities and as monuments to the Medici. They were objects he had carved out of the state of nature for his patrons, and yet they were not like a statue chiseled out of a block of marble. They were not cast as artifacts Galileo had shaped with his hands and then sold to his patron. Nor were

91 Galileo requested Kepler's Ad Vitellionem paralipomena from Giuliano de' Medici on October 1, 1610 (Galilei 1890-1909, X:402, 441). By December 1612 he had also a copy of Kepler's Dioptrice (ibid. XI:813,448). Tarde's remarks are in "Dal Diario del Viaggio di Giovanni Tarde in It alia" (ibid. XIX:590), 
they a work of art the Medici held and controlled as their property - objects they could keep in their galleries. They were tied symbolically to Florence and the grand duke only through their name - a name that had been legitimately given them by their original discoverer. The Medicean Stars were a "natural monument," something that was simultaneously natural and artifactual, global and local. One could think of them as a peculiar artwork - an artwork that was globally visible because the Medici had "loaned" it to all viewers at once.

The hybrid economy of the Medicean Stars matched the hybrid kind of credit Galileo received from them. He was neither a modern scientific author who put his work in the public domain in exchange for professional credit, nor an inventor who fully relinquished his rights by selling his work to a specific buyer in a specific place. He dedicated (but did not really sell) his discoveries to the Medici, because they were not something he could truly sell. The Medici gave him both financial rewards (of the kind given to artists or inventors who sell their work) and more symbolic recognitions (such as the title of philosopher) because what he gave them was not a piece of property exchangeable through monetary transactions. And because the Medicean Stars were not really sold to the Medici, Galileo could also put them in the "public domain" by communicating their finding to non-Florentine audiences (and receive non-financial, philosophical credit from them). ${ }^{92} \mathrm{His}$ function as author was equally hybrid: he was the discoverer of his patron's Stars. Like a court artist who could be famous and yet remain someone's artist, Galileo could only be the personal philosopher of the grand duke of Tuscany.

\section{The Importance of Being Foreign}

The tension between the local and global scale of Galileo's credit and the market of his discoveries can be traced to the hybrid kind of expertise and disclosure necessary to secure their acceptance and reward.

Inventions were evaluated locally, their reward was financial, and the process required little or no disclosure. Instead, the evaluation of later scientific discoveries depended on the judgment of a non-local community (a judgment that was based on the information disclosed by the author) and the discoveries were rewarded with philosophical credit, not money. The Medicean Stars fell in between. They were not assessed solely by a local patron nor by a global community, but through a hybrid arrangement in which a few external evaluations were brought to the local patron who integrated them with his own judgment. Similarly, their reward was neither fully local and financial nor completely global and philosophical. Disclo-

92 As Merton has discussed in the case of modern science, eponymy is made possible by the fact that scientists do not receive direct monetary credit from their discoveries as they could, instead, from their inventions (Merton 1973, 286-324). Because they cannot claim real property on their findings, they may attach their names to them as a gesture of symbolic ownership for their work. In this case, however, eponymy was tied to the patron's (not the discoverer's) name. 
sure requirements were selective too. A textual account of the discovery was made public, but telescopes were made available only to the patron and his peers (not to other astronomers), and the specifications of the instrument that made the Stars visible remained undisclosed and proprietary (as in the economy of invention).

The protocols of their evaluation were hybrid. Practices of philosophical legitimation and peer-evaluation were largely alien to the economy of inventions, but became increasingly important in the economy of discoveries. Inventions were rewarded because of their local usefulness, not because of their non-local truth status. Instead, the Stars' acceptance and reward did not result exclusively from a transaction in which the Medici "bought" the Stars because of their material usefulness to their house. Philosophical considerations about the truth of Galileo's findings (not just their usefulness for his local patron) did matter, as did the views of his peers (not just of his patrons). The process through which the Stars were evaluated and rewarded was a process that combined elements of the economies of invention and discovery. It was predicated on the Medici's perception that the Stars had a degree of usefulness (usefulness that offset the risks they would have taken by "buying" them), but the meaning of "usefulness," "risk," and "buying" was much less financial, material, and local than it was in the economy of invention.

Again, a comparison between Venice and Florence, between local and non-local markets, may shed some light on these differences. In Venice Galileo needed only to convince elderly senators to climb up the many steps to St. Mark's tower. Once up there, the breathless elders were as qualified as anyone else to realize that Galileo's telescope made distant ships visible. They didn't need to consult experts from outside Venice, nor did they want to do that because it was in their interest to keep that invention as secret as possible. This, however, does not mean that the senators were "experts" in telescopic matters, but only that they saw enough military potential in that instrument to be willing to invest in it. And, in any case, all they were risking was a limited amount of money - Galileo's salary raise at Padua.

Instead, Galileo's success at showing Cosimo 11 the Medicean Stars on a number of different occasions in April 1610 was a necessary (but not sufficient) step toward sealing his court appointment. ${ }^{93}$ Although the grand duke appeared to be sufficiently impressed by what he was shown and let Galileo know that a position for him was in the making, he waited until July to make his offer official (Galilei 1890-1909, X:359, 400-1) ${ }^{94}$ Kepler's endorsement of Galileo's claims in the Dissertatio and the positive reception of the Nuncius played a crucial role in

93 In a June 25 letter, Galileo remarks that the grand duke "col proprio senso ha piu'volte veduto" (Galilei 1890-1909, X:339, 382). This claim was repeated in August. There Galileo added that Giuliano de'Medici and many other courtiers had witnessed the satellites as well (ibid., X:379,422). In a May letter to Vinta, Galileo reminds him of what he had told him during his visit to Pisa regarding the possibility of a position at the Florentine court (ibid. X:307, 350).

94 For a discussion of the grand duke's protracted hesitation, see Biagioli1993, 133-9. 
moving the Medici toward the final contract. But this does not mean that without Kepler's endorsement the Medici could not have trusted their own eyes or could not have found professionally qualified local talent to assess Galileo's claims. Because of the scale of the market the Stars were supposed to reach, the question faced by the grand duke was not primarily who had the necessary expertise to certify the Stars, but where that person needed to be.

The telescope was to be used locally in Venice, and its buyers had a clear idea of the material advantages it could provide. ${ }^{95}$ Instead, the Medicean Stars' market was global, the grand duke did not have a clear sense of their potential usefulness for the house of Medici, and such usefulness was symbolic, not material (and therefore difficult to assess). Similarly, the risk the Medici would be taking by accepting the Stars was more symbolic than financial (but serious nevertheless). Had the Stars proved artifactual, the laughter of other princes would have hurt much more than wasting some money on Galileo's salary. Galileo's framing his discoveries in the Medici's dynastic mythologies did help the grand duke realize what he could gain from his Stars (Biagioli 1993, 103-57). ${ }^{96}$ But the Medici were not the sole prospective users of the Medicean Stars - objects whose appreciation needed to exceed the Florentine market. Consequently, they could no longer do a "consumer test" on themselves like the Venetian senators had done with the telescope. They needed a third opinion.

At the same time, the Medici saw the Stars more as a monument (with peculiar visibility requirements) than as an object of knowledge. The Stars were not just an item of private knowledge that needed to be rendered public so that it could travel reliably outside of Florentine settings. Given the economy in which the Medici operated, the issue was not how to "blackbox" the Stars, but how to "sell" them as broadly as possible. Like the Venetian senators, the Medici thought primarily in terms of usefulness, investment, and risk, and less in terms of philosophical legitimation and peer-evaluation. Therefore, when the grand duke looked for external endorsements of the Stars, he acted like a company that seeks consumer opinions from its products' projected market niches, not opinions of experts qualified to certify the truth of Galileo's claims. Had he needed trustworthy people who could confirm Galileo's observations, the grand duke could have found them in Florence (and he was one of them). ${ }^{97}$ What mattered the most, instead, were the

95 Furthermore, the senators did not have to assess the absolute quality of the instrument, but whether it was good enough (i.e. worth the money), and how it performed in comparison to other instruments they had seen before. An August 1609 letter from Venice reports that the senators took the low-power telescope offered by a foreign artisan to the top of St. Mark's tower (Galilei 1890-1909. $\mathrm{X}: 227,250$ ). This is exactly what they did with Galileo's instrument a few weeks later. While the senators had to compare two instruments and assess their relative usefulness, the Medici were asked to cndorse the existence of the Stars, that is, to make an absolute claim.

96 Some of my claims have been disputed by Michael Shank (Shank 1994,236-43). My response is in Biagioli 1996b, 70-105.

97 Not only had the grand duke seen the satellites of Jupiter several times in April with his courtiers, but he also observed the moon together with Galileo with one of his very early telescopes in the autumn of 1609 ("Che la luna sia un corpo similissimo alla terra, già me n'ero accertato, et in parte 
views of foreign experts, not because they were more qualified but because they were foreign (because they spoke from where the Stars were supposed to go).

Kepler's early endorsement was crucial despite the fact that he was unable to replicate Galileo's observations at that time. It was crucial because Kepler was a well-qualified practitioner and bore the prestigious title of "Imperial Mathematician," but even more because Kepler was in Prague, not Florence. His "expertise" was a philosophic-economic hybrid: it was partly rooted in his professional credentials and partly in his physical location in an external market niche. And Prague was a key market because it was in places like the Imperial court that the glory of the Medici was supposed to be appreciated, not because it constituted an important node in the philosophical community. Kepler could have been wrong, and yet his endorsement told the grand duke that the Medicean Stars were likely to be celebrated in Prague (or that the Emperor would have shared in the flop).

The workings of this hybrid economy help to explain Galileo's aggressive distribution of telescopes to princes and cardinals. On March 19, between the publication of the Nuncius and his trip to Florence, Galileo wrote the Medici secretary that to celebrate the Grand Duke's glory in an appropriate fashion,

it would be necessary to send to many princes, not only the book, but also the instrument, so that they will be able to verify the truth. And, regarding this, I still have ten spyglasses which alone among hundred and more that I have built with great toil and expense are good enough to detect the new planets and the new fixed stars. I thought to send these to relatives and friends of the Most Serene Grand Duke, and I have already received requests from the Most Serene Duke of Bavaria, the Most Serene Elector of Cologne, and the Illustrious Cardinal del Monte. ... I would like to send the other five to Spain, France, Poland, Austria, and Urbino, when, with the permission of the Grand Duke, I would receive some introduction to these princes so that I could hope that my devotion would be appreciated and well received. (Galilei 1890-1909, X:277, 298)

The secretary agreed. He replied: "Our Most Serene Lord agrees that the news [of the discovery] should spread and that telescopes should be sent to princes. He will make sure that they will be delivered and received with the appropriate dignity and magnificence" (ibid., X:285, 308).

By giving telescopes to princes and cardinals, Galileo was trying to get credit from important people who were not going to become his competitors. ${ }^{98}$ But he

fatto vedere al Serenissimo Nostro Signore, ma però imperfettamente, non avendo ancora occhiale della eccellenza che ho adesso" (Galilei 1890-1909, X:62, 280). Since then, the grand duke showed himself extremely interested in the telescope and its development (well before Galileo's discoveries) and even helped Galileo's work by sending him in Padua glass blanks made to his specifications by Medici artisans in Florence ("gli si mandano i cristalli conforme all'avviso suo" (ibid. X:240, 259). Galileo's visit to Florence in the fall of 1609 is not mentioned explicitly in any of his letters, but hints can be found in ibid. X:247, 262;250, 265;254, 268.

98 Courtly audiences were not risk-free. Princes tended to ask their mathematicians and philo- 
did not treat them as Collins-style "core sets" - colleagues whose authority could certify new knowledge (Collins 1985, 142-7). Rather, he treated princes the way he had treated Venetian senators when, as an inventor, he had approached them a few months before. While in 1610 he marketed the Medicean Stars and the telescope (not the telescope alone), he repeated on a much larger scale what he had done locally in Venice in 1609. Also, at this time he acted as the Medici's "sales representative," not as an individual inventor. He hoped that, at each site, princes would "buy" (from the Medici and him) a package including the telescope, the Nuncius, and the Medicean Stars the way the senators had bought the telescope (from him) before. The process was analogous: it did not involve disclosure, blackboxing, or optical explanations but just the purchase (symbolic, not monetary) of what, for lack of a better term, I would call a "discovention."

After bringing Kepler's endorsement to Florence, Galileo was told that his position at the Florentine court was almost a fait accompli (Galilei 1890-1909, $\mathrm{X}: 307,350$ ). At this point he started acting like an inventor who, having been rewarded by his prince for his work, did not care very much if other artisans could not reproduce his invention elsewhere. The endorsement from Prague seemed to be all he had needed from the republic of letters. He did not treat Kepler as a colleague, but as someone who just read the Nuncius competently and did not deserve any special sign of reciprocity (such as, for example, a good telescope).

With the grand duke on board, Galileo did not seem to worry about finding further witnesses to his discoveries. In August 1610, Kepler wrote Galileo asking for names of people who had seen the satellites (as well as for the usual telescope), so that he could use them to silence the critics who were still active in Prague (ibid. X:374, 416). Galileo replied:

You, dear Kepler, ask me for other witnesses. I will offer [the testimony of] the Grand Duke of Tuscany who, a few months ago, observed the Medicean Stars with me at Pisa, and generously rewarded me... I have been called back to my fatherland, with a stipend of one-thousand scudi a year, with the title of Philosopher and Mathematician of His Highness, with no duties but plenty of free time. (Ibid. X:379, 422)

While Galileo may not have been able to mention Cosimo II as a witness in a written rebuttal to the mathematicians and philosophers who had questioned his claims (as that would have not been appropriate to the prince's honor), the Grand Duke gave him a position and title that, in that economy, was much more effective than a testimonial from a philosophically qualified practitioner.

Galileo was able to achieve a striking reversal: he acted as if his colleagues'

sophers for their opinions about Galileo's claims, and there was no guarantee that these would be positive ones. But if Galileo could not control these debates, he could expect the princes to have a relatively benign disposition toward his discoveries because of their familiarity with telescopes and of the respect they were expected to demonstrate towards the Medici (Biagioli 1993, 96-8). 
difficulties to replicate his discoveries were to be read as signs of his own authority, not of the possibly problematic status of his claims. He almost turned his telescope into a "mystery," a sign of his "uniqueness." If people still had difficulties replicating Galileo's discoveries, it was their problem - a problem which confirmed that Galileo's telescopes were better than theirs. Now he could wait comfortably and work at producing more discoveries (as he did). The Jesuits'endorsement was still very important, but now Galileo could wait for them to corroborate his findings and go to Rome (as he did in the Spring of 1611) to be celebrated, not to help them with observations.

\section{Conclusion}

One always discloses in order to gain credit. Today, those who publish a discovery or invent a device always give something away in the process of getting their claims recognized or their devices patented. Competitors may be able to use the publication of a patent to circumvent it (or use it for free once it expires), and the publication of a scientific claim can allow other scientists to make further related discoveries and take credit for them. At the same time, discoverers or inventors receive something in return for disclosure. A scientist receives professional credit from publications, and a patent-holder is granted a temporary monopoly of the invention he/she has registered. Galileo operated in a different economy, one in which the checks and balances between credit and disclosure were drawn and managed differently.

The analysis of Galileo's monopolistic tactics has provided a window on the dynamics of the field in which he operated. Along the way, I have tried to show that these tactics were part of economies which constituted the objects they rewarded, not just the modalities of their crediting. Depending on the economies in which it circulated, Galileo's work could be put in different boxes (invention, discovery, artwork), each of them attached to different standards of visibility, disclosure, and secrecy - practices that framed the conditions of acceptance of that work. The boundaries between these economies, however, were far from natural. Galileo's tactics changed between 1609 and 1610 , but not because his work had neatly evolved from "invention" to "discovery." The telescope and the Medicean Stars were different kinds of objects not by virtue of some essentialist taxonomy but because their features made them potentially suitable for different markets - markets of different scales, notions of usefulness and value, and kinds of reward. While the line between invention and discovery has come to demarcate two different regimes ("economic" and "scientific"), this example indicates that what we are looking at are, in fact, two economies (not an economy opposed to a non-economy).

By reframing the context in which Galileo operated, I have argued that the making and reception of his findings were both simpler and more complicated 
than previously thought. Simpler because, in my view, their observation did not depend on opaque perceptual dispositions or on tacit instrument-making skills. More complicated because the process was time-consuming and took place in a field whose members operated in different social and disciplinary economies, and because there was no ready-made "market category" in which Galileo's discoveries could be placed, assessed, and then rewarded in the way he wished them to be. I do not claim that Galileo's discoveries were facts that could be recognized as such once the "accidental" obstacles produced by his uncooperativeness could be removed, or that the debate could have been much shorter had his critics not attacked him with "obscurantist" arguments or had they not refused to take the time to observe. Once we understand these actions in the economies in which they took place, they no longer appear to be passive obstacles. Galileo's tactics (as well as those of his competitors and critics) were not accidental constraints on the path to truth, but constitutive elements of the production of the objects he called "Medicean Stars."

\section{Acknowledgments}

An early version of this paper was delivered at Harvard in July 1994. Since then, I have accumulated many debts of friendship with those who commented on this essay in its several oral and written embodiments: Jim Bennett, Allan Brandt, Bernard Cohen, Sande Cohen, Lorraine Daston, Peter Dear, Yehuda Elkana, Rivka Feldhay, Maurice Finocchiaro, Alan Franklin, Peter Galison, Owen Gingerich, Philippe Hamou, Roger Hart, Steve Harris, Matt Jones, Nick Jardine, Rob Kohler, Peter Machamer, Everett Mendelshon, Katy Park, Jürgen Renn, Simon Schaffer, Randy Starn, Noel Swerdlow, Sherry Turkle, Marga VicedoCastello, Norton Wise, and many others whose names I'll suppress in an attempt to maintain a semblance of authorship in this text. Special thanks to Al Van Helden, my advisor in res telescopica, with whom I have discussed this essay since its very inception (but who is not responsible for any mistakes I may have made). 


\section{References}

Biagioli, Mario. 1993. Galileo Courtier. Chicago: University of Chicago Press.

- 1995. "Knowledge, Freedom, and Brotherly Love: Homosociality and the Accademia dei Lincei, 1603-1630." Configurations 3:139-66.

- 1996a. "Etiquette, Interdependence, and Sociability in Seventeenth-Century Science." Critical Inquiry 22:193-238.

—. 1996b. "Playing with the Evidence." Early Science and Medicine 1:70-105.

- Forthcoming. The Check is in the Mail.

Bloom, T. 1978. "Borrowed Perceptions: Harriot's Maps of the Moon." Journal for the History of Astronomy 9:127-22.

Bourdieu, Pierre. 1985. "Social Space and the Genesis of Groups." Theory and Society 14:723-44.

- 1999. "The Specificity of the Scientific Field and the Social Conditions for the Progress of Reason." In The Science Studies Reader, edited by Mario Biagioli, 31-50. New York: Routledge.

Chalmers, Alan. 1990. Science and Its Fabrication. Minneapolis: University of Minnesota Press.

Cohen, Bernard. 1993. "What Galileo Saw: The Experience of Looking Through a Telescope." In From Galileo's "Occhialino" to Optoelectronics, edited by P. Mazzoldi, 445-472. Padova: Cleup Editrice.

Collins, H.M. 1985. Changing Order. London: Sage.

Dear, Peter. 1995. Discipline and Experience. Chicago: University of Chicago Press.

Drake, Stillman. 1970. "Galileo and the Telescope." In Galileo Studies, 142-4. Ann Arbor: University of Michigan Press.

- . 1976a. "Galileo's First Telescopic Observations." Journal for the History of Astronomy 7:153-168.

- 1976b. The Unsung Journalist and the Origin of the Telescope. Los Angeles: Zeitlin \& ver Brugge.

- 1978. Galileo at Work: His Scientific Biography. Chicago: University of Chicago Press.

- 1979. "Galileo and Satellites Prediction." Journal for the History of Astronomy 10:75-95.

Edgerton, S. 1984. “Galileo, Florentine ‘Disegno' and the 'Strange Spottedness' of the Moon." Art Journal Fall:225-232.

Favaro, Antonio. 1983. Amici e corrispondenti di Galileo. Edited by Paolo Galluzzi. Florence: Salimbeni.

Feyerabend, P. 1978. Against Method: Outline of an Anarchistic Theory of Knowledge. London: Verso.

Galilei, Galileo. 1613. Istoria e dimostrazioni intorno alle macchie solari e loro accidenti: comprese in tre lettere scritte all'illustrissimo signor Marco Velseri. Roma: Mascardi. 
- 1890-1909. Le opere di Galileo Galilei. Edited by Antonio Favaro. Florence: Barbera.

- 1957. Discoveries and Opinions of Galileo. Translated by Stillman Drake. New York: Doubleday.

- 1989. Sidereus nuncius: or the Sidereal Messenger. Translated with introduction, conclusion, and notes by Albert Van Helden. Chicago: University of Chicago Press.

Horky, Martinus. 1610. Brevissima peregrination contra nuncium sidereum. Modena: Cassiani. (Reprinted in Galilei 1890-1909, III, Part 1:129-45).

Gerulaitis, Leonardas Vytautas. 1976. Printing and Publishing in FifteenthCentury Venice. Mansell: London.

Humbert, Pierre. 1948. "Joseph Gaultier de la Vallette, astronome provencal (1564-1647)." Revue d'histoire des sciences et de leurs applications 1:316.

Kepler, Johannes. 1606. Narratio. Pragae: Ex Officina calcographica Pauli Sessii.

- 1611. Narratio de observatis a se quatuor Iovis satellibus erronibus. Frankfurt: Palthenius. (Reproduced in Kepler 1941, Band IV:317-25).

- 1941. Gesammelte Werke. Munchen: Beck'sche Verlagsbuchhandlung.

- 1965. Conversation with the Sidereal Messenger. Translated by Edward Rosen. New York: Johnson.

Machamer, Peter K. 1973. "Feyerabend and Galileo: The Interaction of Theories, and the Reinterpretation of Experience." Studies in History and Philosophy of Science 4:1-46.

McLeod, Christine. 1988. Inventing the Industrial Revolution. Cambridge: Cambridge University Press.

Meeus, Jean. 1964. "Galileo's First Records of Jupiter's Satellites." Sky and Telescope 27(2):105-6.

Merton, Robert. 1973. "Priorities in Scientific Discoveries." The Sociology of Science: Theoretical and Empirical Investigations. Chicago: University of Chicago Press.

Prickard, A.O. 1916. “The 'Mundus Jovialis' of Simon Marius.” The Observatory 39:367-503.

Roche, John. 1982. "Harriot, Galileo, and Jupiter's Satellites." In Archives internationales d'histoire des sciences 32:9-51.

Rosen, Edward. 1954. "Did Galileo Claim He Invented the Telescope?" Proceedings of the American Philosophical Society 98:304-12.

Schaffer, Simon. 1989. "Glass Works: Newton's Prism and the Uses of Experiment." In The Uses of Experiment, edited by David Gooding, Trevor Pinch, and Simon Schaffer, 67-104. Cambridge: Cambridge University Press.

Shank, Michael. 1994. "Galileo's Day in Court." Journal for the History of Astronomy 25:236-43.

Shapin, Steven. 1984. "Pump and Circumstance: Robert Boyle's Literary Technology." Social Studies of Science 14:481-520. 
Shapin, Steven and Simon Schaffer. 1985. Leviathan and the Air Pump. Princeton: Princeton University Press.

Sirtori, Girolamo. 1618. Telescopium: sive ars perficiendi. Frankurt: lacobi.

Sizi, Francesco. 1611. Dianoia astronomica, optica, physica. Venice: Bertani. (Reprinted in Galilei 1890-1909, III, Part 1:203-50).

Van Helden, Albert. 1974. "The Telescope in the Seventeenth Century." Isis 65:38-58.

- 1977. "The Invention of the Telescope." Transactions of the American Philosophical Society 67(4):1-67.

- 1984. "Galileo and the Telescope." In Novità celesti e crisi del sapere. Edited by Paolo Galluzzi, 150-7. Florence: Giunti.

—. 1989. "Introduction." In Sidereus nuncius: or the Sidereal Messenger. Translated by Albert Van Helden, 10-6. Chicago: University of Chicago Press.

Van Helden, Albert, and Mary Winkler. 1992. "Representing the Heavens: Galileo and Visual Astronomy." Isis 83:207-6.

- 1994. "Telescopes and Authority from Galileo to Cassini." Osiris 9:19.

Whitaker, Ewan. 1978. "Galileo's Lunar Observations and the Dating of the Composition of the 'Sidereus nuncius'." Journal for the History of Astronomy 9:155-69. 